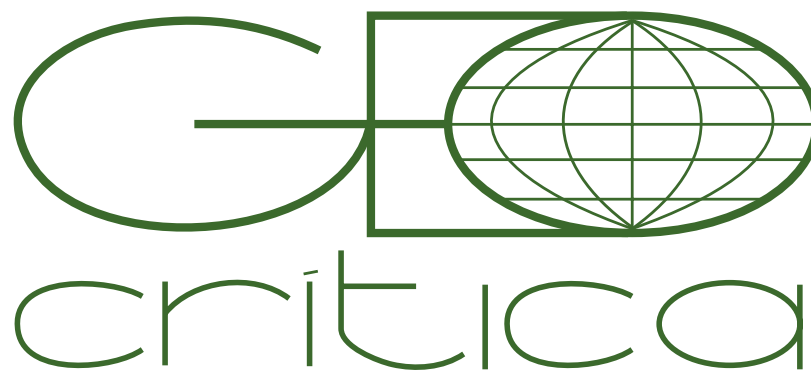

\section{Scripta Nova}

Revista Electrónica de Geografía y Ciencias Sociales Universitat de Barcelona

15 de abril de 2018

\title{
LA APUESTA POR EL PATRIMONIO HISTÓRICO-ARTÍSTICO EN EL TURISMO DE MONTAÑA. EL CASO DEL PIRINEO CATALÁN
}

\author{
Martí Cors i Iglesias \\ Departament de Geografia. Universitat de Barcelona \\ marti.cors@ub.edu \\ M. Belén Gómez Martín \\ Departament de Geografia. Universitat de Barcelona \\ bgomez@ub.edu \\ Xosé A. Armesto López \\ Departament de Geografia. Universitat de Barcelona \\ armesto@ub.edu
}

Recibido 12 de junio de 2017 Devuelto para correcciones: 24 de julio de 2017 Aceptado 8 de enero de 2018

\section{La apuesta por el patrimonio histórico-artístico en el turismo de montaña. El caso del Pirineo catalán.}

La escasa presión humana sobre los espacios de alta montaña, de características físicas extremas, ha permitido mantener y conservar un patrimonio natural y cultural de innegable valor y atractivo que, con el paso del tiempo, se ha convertido en uno de sus principales activos de desarrollo económico y social. Ante el actual escenario del cambio climático y su impacto sobre el turismo de nieve, las nuevas estrategias de desarrollo turístico relacionadas con el patrimonio cultural y natural cobran notoriedad e importancia y el patrimonio histórico-artístico se posiciona como un activo destacado de territorio, que contribuye a diversificar las líneas de producto turístico y a desestacionalizar la temporada.

Palabras clave: Turismo, patrimonio, montaña, desestacionalización, diversificación, Pirineos

Esta aportación ha sido realizada en el marco del proyecto de $1+D+i$ con referencia CSO2014-51866-R del Programa Estatal de Investigación, Desarrollo e Innovación Orientada a los Retos de la Sociedad del Ministerio de Economía y Competitividad del Gobierno de España..
The commitment to the historical-artistic heritage in mountain tourism. The case of the Catalan Pyrenees.

The scarce human pressure on the high mountain spaces, of extreme physical features, has allowed to maintain and preserve a natural and cultural heritage of undeniable value and attractiveness that down of time has become one of its main assets of economic and social development. Given the current scenario of climate change and its impact on snow tourism, new tourism development strategies related to cultural and natural heritage are notorious and important, and the historical and artistic heritage is a prominent asset of the territory, which contributes to diversify and to deseasonalise the tourist product lines.

Keywords: Tourism, heritage, mountain, deseasonalization, diversification, Pyrenees 
Los espacios de montaña cuentan con una larga tradición turística, que en Europa se remonta a finales del siglo XVIII e inicios del XIX, cuando durante el Romanticismo los intelectuales se sentían atraídos por la belleza y grandiosidad de sus paisajes. Unos espacios apreciados por las clases sociales más privilegiadas como lugares de ocio y descanso durante los meses de verano. Tanto la aristocracia como la burguesía disfrutaban del contacto con la montaña y la naturaleza; una estima que hoy en día vuelve a estar de moda, estimulada por los valores medioambientales presentes en amplios segmentos de la población y que, desde el punto de vista turístico, incentivan la puesta en valor del patrimonio paisajístico.

La llegada del turismo de nieve supuso un cambio muy importante para los territorios de montaña: se inició un proceso de desestacionalización, con la presencia de turistas durante los meses invernales, y se transformó el tejido productivo local, con un fuerte crecimiento del sector servicios. Un turismo de nieve, que a partir de los años cincuenta y sesenta, y de acuerdo con el modelo de producción fordista de la época, tiende a la masificación y a la configuración de amplios complejos turísticos en altura, con un importante volumen de negocio a su alrededor y una transformación del territorio desde el punto de vista social, económico y urbanístico. El éxito de los grandes dominios esquiables, en términos económico-empresariales y turísticos, condujo a su proliferación y expansión por las cordilleras europeas, siendo un modelo de esperanza ante el éxodo rural y la marginalidad económica de los territorios rurales de alta montaña. No obstante, ni todas las iniciativas relacionadas con el turismo de nieve y la apertura de nuevas estaciones de esquí fueron rentables desde el punto de vista económico, ni produjeron los efectos deseados en relación al desarrollo local.

Con la aparición de nuevos intereses e inquietudes por parte de la demanda turística, y de acuerdo con los postulados de producción postfordista, en el transcurso de los años ochenta y noventa se produce un rápido proceso de diversificación turística, con la puesta en valor de nuevos recursos y la aparición de nuevos productos en espacios rurales y de montaña (turismo rural, de naturaleza y cultural). La riqueza patrimonial del propio territorio y su puesta en valor por parte de los distintos actores implicados contribuye a la generalización espacial de la actividad turística, incluso en aquellos territorios más alejados de la influencia directa de las estaciones de esquí, y al incremento de la demanda durante los períodos vacacionales. La especialización y dependencia de las economías del territorio en relación al turismo van al alza y el patrimonio es contemplado como oportunidad de desarrollo, no tan solo en términos de rentabilidad económica, sino también, en beneficio de las comunidades locales (conservación de los elementos culturales e identitarios). Una valorización patrimonial y turística de los espacios de montaña que aparece en distintas cordilleras del Planeta, como lo ejemplifican los casos de la Ruta de la Plata andina ${ }^{1}$ o el Camino Inca².

1 Moreno y Pereira, 2011.

2 Martínez, 2009. 
A pesar del éxito turístico de la montaña en cuanto a imagen y popularidad, especialmente en Europa, aparecen nuevos retos e incertidumbres para el sector como los asociados al cambio climático y sus posibles efectos sobre el turismo, en especial sobre el turismo de nieve. En este contexto, la diversificación de productos turísticos es señalada como una de las estrategias fundamentales de adaptación al cambio climático, en el ámbito de las políticas y de las prácticas de gestión empresarial ${ }^{3}$. Esta medida, que permite ampliar las líneas de producto en un determinado destino/región turística o empresa ${ }^{4}-y$, por tanto, implementar más productos, con diferentes requerimientos atmosféricos y con menor dependencia de las condiciones climáticas-, podría dotar al sector de una menor vulnerabilidad frente al cambio climático y también frente al clima y la variabilidad actual del mismo ${ }^{5}$. La diversificación de la oferta y productos turísticos, que permita, a la vez, una mayor desestacionalización de la actividad en zonas de montaña, debería favorecer la capacidad de adaptación del sector turístico al cambio climático y romper, de este modo, la excesiva dependencia de los territorios de alta montaña en relación al turismo de nieve. En este caso, el auge del turismo rural y cultural, basado en la valorización de los recursos patrimoniales, contribuye a ampliar y diversificar la oferta de productos turísticos en zonas de montaña6.

El presente artículo pone el foco de atención en el patrimonio cultural y su dimensión turística y, en particular, en el análisis del patrimonio histórico-artístico en un espacio de montaña. El marco territorial de estudio es la región del Alt Pirineu i Aran, situada en el cuadrante noroccidental de Cataluña, en plena cordillera pirenai$\mathrm{ca}^{7}$. Tras abordar el marco teórico sobre patrimonio y turismo y su contextualización territorial, el artículo evalúa la presencia territorial y el uso turístico del patrimonio histórico-artístico, representado por el arte románico, y hace hincapié en las ventajas que supone el uso adecuado del patrimonio para los procesos de diversificación y desestacionalización turística y, en definitiva, para el desarrollo territorial. Para finalizar, a partir del caso de la Vall de Boí, el artículo analiza la dimensión turística del patrimonio histórico y explora su relación, en términos de complementariedad, con el modelo tradicional de turismo de nieve.

\footnotetext{
3 Gómez et al., 2014.

4 Desde la óptica empresarial, una de las estrategias adoptadas por el sector es la reconversión de las estaciones de esquí en estaciones de montaña, donde se practiquen otras actividades al aire libre no relacionadas con el recurso nieve más allá del período invernal. Pero a nivel de territorio, fuera del ámbito estricto de la estación de esquí, las estrategias de adaptación se diversifican, siendo más compleja su concreción.

5 Fraguell et al., 2016.

6 Gómez, 2005.

7 La región del Alt Pirineu i Aran abarca los límites administrativos de la actual Vegueria del Alt Pirineu i Aran, definida en el anteproyecto de Ley de Organización Veguerial de Cataluña e integrada por las comarcas del Alt Urgell, Alta Ribagorça, Cerdanya, Pallars Jussà, Pallars Sobirà y el territorio del Aran. En 2006 es aprobada por el nuevo Estatuto de Autonomía de Cataluña, que establece la Vegueria como división territorial con personalidad jurídica propia.
} 


\section{Patrimonio, territorio y turismo}

El término "patrimonio" -de amplio uso y divulgación- ha despertado un interés creciente en los últimos años, siendo objeto de reflexión en múltiples foros y debates. Constituye un término complejo por su diversidad semántica reflejada en los calificativos que le suelen acompañar: natural-cultural, material-inmaterial, tangible-intangible, urbano-rural, artístico, arqueológico, etnográfico, etc ${ }^{8}$. El uso de la acepción ha ido cambiando a lo largo del tiempo. Una evolución conceptual del término "patrimonio" que ha pasado de una visión más restringida, asociada al reconocimiento de los monumentos históricos y espacios naturales emblemáticos, a una noción más amplia e integral, con la incorporación de las manifestaciones inmateriales y la introducción del concepto paisaje como producto de la relación entre patrimonio natural, histórico y cultural. Como resultado de la estrecha relación existente entre patrimonio, paisaje y territorio se ha acuñado una nueva denominación, la de "patrimonio territorial", definido según José Ortega Valcárcel", como "el conjunto de recursos tanto naturales como culturales heredados en un espacio geográfico dado, con un elevado grado de aceptación y reconocimiento social". Ambas relaciones, patrimonio-paisaje y patrimonio-territorio, han sido tratadas por los geógrafos españoles en numerosos estudios ${ }^{10}$, ya que "el patrimonio constituye un magnífico instrumento para explicar la historia de un territorio y de la sociedad que lo ha habitado"11 que, además, actúa como factor de localización de actividades económicas -entre ellas la turística- ${ }^{12}$. Los recursos patrimoniales, naturales, culturales y paisajísticos son necesarios para construir una alternativa realista al actual modelo de crecimiento porque, como se viene señalando desde la economía ecológica, Río +20, el panel del cambio climático o el grupo de expertos de las Naciones Unidas sobre sostenibilidad, de no caminar en esta dirección no solo será imposible superar la crisis actual sino que también se estaría poniendo en riesgo la propia presencia del hombre.

La dimensión territorial del patrimonio está relacionada con las características del medio físico donde se localiza pero fundamentalmente con la historia y la cultura del lugar. Por su relevancia territorial desempeña un papel importante en las políticas de desarrollo local ya que contribuye a reforzar nuevas identidades y crear nuevos espacios de desarrollo. En definitiva, el territorio pasa de ser un simple soporte físico para el desarrollo de actividades a ser un recurso, un valor y un agente de desarrollo, que interviene de forma activa en los procesos de "patrimonialización espacial" ${ }^{13}$.

8 Porcal, 2011.

9 Ortega, 1998.

10 Gómez, 2013; Martín, 2016; Albarrán, 2016; Ojeda, 2004; Troitiño, 2015; Pillet, 2011, Cañizares, 2011, Silva, 2009, Silva y Fernández, 2017, Doctor, 2011, y Capel, 2014.

11 Troitiño, 1998.

12 Graham et al., 2000.

13 Troitiño, 2016. 
En relación al patrimonio cultural, cabe señalar que no se limita al concepto histórico-artístico sino que también engloba los rasgos inmateriales o intangibles que caracterizan a una sociedad o grupo social. El turismo cultural, en definitiva, se sustenta sobre una amplia gama de recursos y productos relacionados con la humanidad, que según Miguel Ángel Troitiño ${ }^{14}$, y para el ámbito rural, pueden agruparse en base a las siguientes tipologías: a) recursos histórico-culturales, de naturaleza muy diversa y con elevadas potencialidades para la revalorización turística del medio rural; b) recursos ambientales, elementos del paisaje que le confieren un alto grado de atracción para el visitante; c) recursos paisajísticos, que en el medio rural tienen un significado importante; y d) recursos etnológicos-antropológicos, representados por el conjunto de costumbres y tradiciones.

Los inicios del proceso de valoración patrimonial se sitúan en el siglo XIX con la realización de inventarios y catálogos formales. Estos son los que verdaderamente crean y consagran el patrimonio ${ }^{15}$, incentivando el surgimiento de organismos relacionados con la protección del mismo a escala estatal y regional. Se elaboran normas y leyes, primero para la protección de los grandes monumentos y, más tarde, para todos aquellos que han tenido algún valor histórico o artístico. Muchas veces es el proceso de inventario y catalogación el que verdaderamente da significado a los hitos patrimoniales y permite tomar conciencia de su valor, y el turismo el que contribuye a su difusión entre amplios estratos de la sociedad. En este sentido, la puesta en valor del patrimonio por parte del turismo se lleva a cabo desde intereses y sensibilidades que no siempre coinciden en sus propósitos pero que generalmente suelen producirse bajo el prisma del conocimiento y la conservación.

La relación entre patrimonio y turismo se produce con la democratización del turismo a partir de los años 1960, cuando la noción de monumento pasa a ser de patrimonio. Un movimiento que en el mundo anglo-sajón lo encontramos bajo el concepto de Heritage con la firma en 1972 de la "Convención del Patrimonio Mundial" (World Heritage) por parte de la UNESCO ${ }^{16}$. Nace así la fórmula de Patrimonio Mundial de la Humanidad para constituir esta nueva alianza de monumentos históricos y naturales y establecer un tipo de protección que mira fundamentalmente la calidad del valor universal excepcional. Este es el punto de partida de una tendencia que se extiende a partir de entonces y que, en relación al turismo, dará lugar a una nueva expresión, la de "turismo patrimonial". El turismo se convierte, por tanto, en un medio de valorización económica del patrimonio y constituye una de las vías para enriquecer los lugares y para que estos lugares sean capaces por ellos mismos de generar nuevas oportunidades de desarrollo turístico ${ }^{17}$. El verdadero valor del patrimonio es que sea reconocido como algo valioso por los miembros de la socie-

14 Troitiño, 1998.

15 Capel, 2014.

16 Según la UNESCO, el término "patrimonio" es concebido como todo aquello que tiene un valor universal excepcional desde el punto de vista de la naturaleza, la historia, del arte o de la ciencia, un patrimonio que apela a valores comunes de la humanidad.

17 Lazzarotti, 2011. 
dad; el turismo y sus distintas modalidades representan una gran oportunidad para poner en valor todos aquellos bienes patrimoniales diseminados por el territorio y posicionar el lugar como destino turístico desde una perspectiva global ${ }^{18}$. Actualmente, los procesos de patrimonialización territorial y desarrollo turístico han alcanzado una dimensión global y se extienden por todo el Mundo.

En el año 2016, la UNESCO contaba con más de un millar de sitios inscritos como Patrimonio Mundial de la Humanidad, repartidos por 165 países. España era, tras Italia, el segundo país con un mayor número de sitios declarados Patrimonio de la Humanidad por la UNESCO, lo que la convierte, a priori, en uno de los principales destinos de turismo cultural del mundo. A pesar de la difícil convivencia, en ocasiones, entre el turismo patrimonial -asociado al territorio y a su cultura- y otros modelos turísticos -como por ejemplo el turismo masivo de sol y playa que ha eclipsado en cierto modo la imagen cultural y patrimonial del país-, el binomio turismo-patrimonio debería alcanzar su máxima expresión y desarrollo en España, más allá de los estrictos ámbitos urbanos formados por la red de ciudades Patrimonio de la Humanidad ${ }^{19}$.

En realidad, las políticas y actores que hay detrás de la toma de decisiones de la UNESCO, y sus repercusiones, tanto a nivel territorial como turístico, son de suma importancia y han despertado un gran interés entre los académicos, con multitud de estudios al respeto. A modo de ejemplo, citar el caso de la Quebrada de Humauaca, en Argentina, declarada patrimonio de la Humanidad en el 2003. Un estudio analiza con detalle las políticas y estrategias utilizadas entorno a dicha declaración y sus efectos a nivel turístico, colocando la zona en un lugar destacado en el conjunto de los destinos turísticos de Argentina ${ }^{20}$.

Tabla 1. El valor semántico del patrimonio y su patrimonialización

\begin{tabular}{|c|c|c|c|}
\hline $\begin{array}{l}\text { Registro semántico } \\
\text { del valor }\end{array}$ & $\begin{array}{l}\text { Orden del } \\
\text { valor }\end{array}$ & $\begin{array}{l}\text { Campo de estudio y/o actividad } \\
\text { social }\end{array}$ & $\begin{array}{l}\text { Objetivo de la } \\
\text { patrimonialización }\end{array}$ \\
\hline Estima & Ético & $\begin{array}{l}\text { Antropológico: relación de la so- } \\
\text { ciedad contemporánea con la na- } \\
\text { turaleza, la cultura y la historia }\end{array}$ & $\begin{array}{l}\text { Preservar, asegurar la } \\
\text { transmisión, en un esta- } \\
\text { do "original". }\end{array}$ \\
\hline Calidad & Uso & $\begin{array}{l}\text { Técnico: utilización de los ele- } \\
\text { mentos patrimoniales (planifica- } \\
\text { ción, arquitectura, ecología) }\end{array}$ & $\begin{array}{l}\text { Ponerlo en funciona- } \\
\text { miento, hacerlo viven- } \\
\text { cial, apoyar la actividad. }\end{array}$ \\
\hline Medida & $\begin{array}{l}\text { Intercam- } \\
\text { bio }\end{array}$ & $\begin{array}{l}\text { Económico: modalidades de in- } \\
\text { serción en el mercado }\end{array}$ & $\begin{array}{l}\text { Atraer a nuevos turistas, } \\
\text { promocionar el territorio } \\
\text { y mostrar su originali- } \\
\text { dad. }\end{array}$ \\
\hline
\end{tabular}

Fuente: Sol, Marie-Pierre.

18 Velasco, 2009.

19 García y Alburquerque, 2003.

20 Troncoso, 2009. 
En el proceso de identificación de los recursos territoriales y su posterior valorización, el valor que adquiere el recurso, posteriormente patrimonializado con fines turísticos, es múltiple y estará en función de los distintos registros semánticos (tabla $1)^{21}$.

De acuerdo con Simón et al. ${ }^{22}$, bajo una concepción mercantilista, el patrimonio se interpreta como aquello que debe satisfacer las necesidades del consumo contemporáneo. Las nuevas corrientes en la gestión del patrimonio optan por la dinamización buscando, además de la necesaria conservación, la rentabilidad y los beneficios económicos. En consecuencia, el patrimonio, trasciende lo puramente cultural y se transforma en un potencial recurso económico. En este sentido, hace falta ser capaces de hacer del turismo una actividad generadora de desarrollo y ayudar a recuperar y poner en valor el patrimonio, dinamizando la economía del territorio.

El patrimonio natural, objeto de valoración social y turística, se integra dentro de un proceso general más amplio de desarrollo del paradigma ecológico y la mayor sensibilidad por el medio ambiente; una consciencia ecológica que defiende el uso adecuado y no agresivo de los recursos naturales y su preservación. La incorporación de los recursos culturales como bienes de consumo sigue cánones muy similares al de los recursos naturales, y se enmarca en los procesos de creación de nuevas necesidades y nuevos consumos que suponen de facto la mercantilización del patrimonio cultural ${ }^{23}$.

En definitiva, ante un mercado turístico global y altamente competitivo, las estrategias de desarrollo turístico pasan por la diversificación, la originalidad y la experiencia vivencial, aumentando de esta forma la potencialidad y valorización turística de los recursos patrimoniales. Los cambios atañen, de igual modo, al comportamiento de la demanda turística en el marco general, caracterizado por el advenimiento de la denominada sociedad de la ilusión (dream society), que sustituye a la sociedad de la información en el mundo desarrollado y en la que el comportamiento emocional (los valores, las emociones y los sentimientos) alcanzan mucha más relevancia que el componente racional. Sin duda, este modelo social crea un nuevo consumidor que no busca ya servicios sino que desea experiencias que satisfagan su sistema emocional, y en las que el patrimonio, en sus distintas manifestaciones, desempeña un papel muy importante.

Ahora bien, que los procesos de patrimonialización y turistificación del territorio sean generalizados no significa que todos los recursos patrimoniales sean turísticamente viables. Según Llorenç Prats ${ }^{24}$, en muchas ocasiones el uso turístico de un recurso patrimonial no tan solo depende de la propia naturaleza del recurso y de la capacidad de atracción turística que tenga por sí mismo, sino que también depende de su cercanía en relación a los principales focos emisores (áreas urbanas), o bien de su ubicación en relación a los principales destinos turísticos. Así, por ejemplo, un

21 Sol, 2007.

22 Simón et al., 2011.

23 López-Palomeque, 2008.

24 Prats, 2011. 
hito patrimonial cuyas características intrínsecas al propio monumento le confiere una escasa capacidad de atracción turística, por el mero hecho de estar situado en una zona turísticamente consolidada, o bien en una zona urbana o cercana a ella, los flujos de visitantes serán suficientes para integrarse con éxito al sistema turístico. En consecuencia, el uso turístico del hito patrimonial puede verse claramente beneficiado o perjudicado por su localización. En este mismo sentido, el diseño-creación de rutas e itinerarios turísticos responde de manera estratégica a la voluntad de incorporar el mayor número posible de hitos patrimoniales al sistema turístico-territorial.

Por otro lado, el binomio patrimonio-turismo no está exento de ciertas complejidades que, a menudo, afloran en el debate. En este sentido, no es tarea fácil conjugar turismo y patrimonio y compatibilizar dos situaciones claramente contradictorias: la conservación frente a la alteración del mismo. En ciertos casos, las degradaciones relacionadas con la sobrefrecuentación mal controlada han conducido a los responsables a aplicar medidas de protección para permitir un desarrollo más sostenible. Las relaciones en ambos casos pueden ser, por tanto, de doble filo y complejas: por un lado, cómo hacer compatible el turismo con la conservación y los usos del patrimonio y, por otro, cómo potenciar las múltiples sinergias que se establecen entre patrimonio y turismo, de tal forma que el patrimonio produzca efectos positivos sobre el turismo y el turismo sobre el patrimonio. El patrimonio, además de referente simbólico y seña de identidad de una sociedad, es también una pieza relevante de la calidad y del atractivo del territorio, pero "la búsqueda de una relación armónica entre patrimonio y turismo es una tarea compleja pues se suelen enfrentar dos racionalidades, la del mercado que persigue la rentabilidad a corto plazo, y la cultural, preocupada por la defensa de valores colectivos de dimensión pública"25.

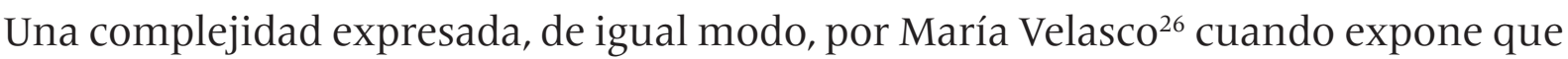
una de las mayores dificultades para la gestión turística del patrimonio cultural reside en el hecho de que el uso turístico de los bienes pone en contacto dos ámbitos de realidades muy distintas: la del sector turístico y el de la cultura. Por tanto, en la vertiente más turística del patrimonio están siempre presentes aspectos y procesos a tener muy en cuenta en clave de amenazas para el propio patrimonio como son la masificación, la falta de autenticidad y/o banalización y la falta de inversión. Y pese a su complejidad, la conservación del patrimonio y su desarrollo en base al turismo no deberían ser entendidos como dos procesos antagónicos dado que sin conservación no es posible garantizar su desarrollo; y bajo el paradigma de la sostenibilidad, el disfrute del patrimonio debe ser compatible con su conservación ${ }^{27}$.

Otro de los aspectos críticos asociados a la puesta en valor del patrimonio como bien de uso turístico es su instrumentalización como elemento de revalorización del suelo urbano, que abre el camino para que el capital privado se acabe apoderando

25 Troitiño, 2015.

26 Velasco, 2009.

27 Pulido, 2013. 
de los mercados inmobiliarios locales. Alfonso Valenzuela ${ }^{28}$ analiza el caso del programa federal denominado "Pueblos Mágicos" en México, que busca capitalizar la cultura y las tradiciones al poner en valor los atractivos turísticos de dichos lugares. Según él, el programa se fue centrando en la dimensión económica, respondiendo a indicadores y parámetros de tipo empresarial y dejando de lado la identidad comunitaria y el bienestar de la población. Sin duda son cuestiones a tener muy en cuenta en todo proceso de valorización y turistificación de los recursos patrimoniales.

\section{Procesos de patrimonialización y especialización turística en espacios de montaña}

Los espacios rurales y de montaña viven desde hace años una revalorización patrimonial que no puede dejar de ser vista como una reacción social frente al desarraigo causado por la aceleración de la vida moderna, por la desertificación de la montaña y por la desaparición de los modos de vida tradicionales. El medio rural adquiere un nuevo valor y es convertido en producto y mercancía que circula en espacios globales y que, según Pereiro ${ }^{29}$, ofrece un paquete emocional que proporciona "tradición", "autenticidad", "naturalidad", todos ellos considerados valores perdidos en los medios urbanos. Para David Harvey ${ }^{30}$, el espacio rural adquiere así una mayor atracción para los habitantes de las ciudades, debido a la "crisis de memoria" asociada a los procesos de globalización y a las transformaciones sociales ocurridas en el espacio y en el tiempo. Los espacios rurales de montaña cada vez se venden más como un producto para el consumo turístico y la sociedad está más interesada que nunca en conocerlos. Por tanto, tanto el campo como la montaña intentan responder a las demandas de una sociedad postindustrial que contempla la naturaleza como valor y bien estético y que mira al mundo rural como el marco para sus actividades de ocio y descanso ${ }^{31}$.

De igual modo, los espacios de montaña presentan características de índole diversa y, a menudo, compleja (diversidad paisajística, fragilidad ambiental y social, idiosincrasia particular) que han favorecido los llamados procesos de patrimonialización territorial bajo el prisma de la preservación y la sostenibilidad. Estos espacios albergan un patrimonio natural y cultural muy variado, que son la base para una amplia gama de productos turísticos: turismo de nieve, de naturaleza, turismo relacionado con el agua, con el patrimonio cultural y el turismo de aventura.

El reconocimiento del patrimonio como factor de desarrollo se inserta en una corriente de recuperación de las áreas rurales de montaña que surge en Europa a partir de los años setenta, pero que no adquiere auténtica dimensión social hasta el último decenio del siglo XX. El interés por las cuestiones patrimoniales deriva de la progresiva consideración de los valores patrimoniales del territorio desde una

28 Valenzuela, 2017.

29 Pereiro, 2009.

30 Harvey, 1989.

31 Simón, 2011. 
perspectiva ambiental o física y de la preocupación social por los procesos de degradación y deterioro asociados al declive social y económico de una gran parte de los espacios de montaña en Europa ${ }^{32}$. Desde los años ochenta, ante el creciente interés y consenso en torno a la idea del desarrollo local, muy articulado en base al turismo, los espacios de montaña están asistiendo a un intenso proceso de difusión de los valores patrimoniales del territorio con la incorporación de los recursos naturales y culturales como elementos de desarrollo económico. En la legislación vigente de algunos países europeos ${ }^{33}$ hay un reconocimiento explícito al patrimonio natural, cultural, arquitectónico y paisajístico de las zonas de montaña ${ }^{34}$, siendo incorporado como elemento de referencia territorial en los distintos instrumentos de planificación territorial, sectorial y urbanística.

A escala mundial, las regiones montañosas con una mayor oferta de productos turísticos derivados de los recursos patrimoniales las situamos en países de gran tradición turística ${ }^{35}$. Para el caso específico de la montaña alpina europea, su especialización turística a partir de los años sesenta se produce en base al modelo tradicional del turismo de nieve de las estaciones de esquí alpino de segunda y tercera generación (turismo masivo invernal). La aparición más tardía de nuevas prácticas turísticas en plena naturaleza (esquí de fondo, senderismo, deportes de aventura), y aquellas otras actividades relacionadas con la cultura, ponen de manifiesto la elevada potencialidad turística de los recursos patrimoniales de la montaña y el interés en que sean estos mismos los que lideren el desarrollo turístico del territorio. Además, la apuesta por el patrimonio se refuerza ante las incertidumbres que presenta el sector tradicional del turismo de nieve por sus elevados costes ambientales y económicos y por los efectos derivados del cambio climático ${ }^{36}$.

A lo largo de las últimas décadas, los espacios rurales de montaña situados fuera del radio de influencia directa de las estaciones de esquí y que mantienen aún su vocación agraria también se han incorporado al sistema turístico gracias al desarrollo del turismo rural. Este proceso está directamente relacionado con el redescubrimiento y la reconversión del espacio-patrimonio rural hacia fines turísticos, y que viene acompañado de la revalorización de aspectos como la autenticidad, la

32 José Ortega Valcarcel, 2004; analiza la complejidad de los espacios montañosos españoles y la evolución de las políticas de desarrollo en las áreas de montaña con un nuevo enfoque integral que supone la consolidación del patrimonio rural de estas áreas y su integración en las políticas de ordenación territorial.

33 La Ley de montaña francesa de 1985 define que "la montaña constituye una entidad geográfica, económica y social, definida por el relieve, el clima, el patrimonio natural y cultural, con la necesidad de aplicar una política específica de desarrollo, planificación y de protección".

34 Gómez, 2010.

35 Vera et al., 2013.

36 El aumento de la temperatura media anual a nivel planetario y un incremento de la irregularidad en las precipitaciones en el área mediterráneo tiene una afectación directa en la presencia y la calidad del manto nival en las estaciones de esquí. Las medidas de adaptación al cambio climático pasan por diversificar y desestacionalizar las actividades en las estaciones de esquí, poniendo en valor los recursos patrimoniales de índole natural y cultural de la zona. Fraguell et al., 2016. 
identidad cultural de los lugares, los orígenes y una concienciación medioambiental de las sociedades urbanas, ${ }^{37}$, ya citadas anteriormente. El auge del turismo acaba materializando mediante la respuesta positiva de los actores locales a los propios estímulos de la demanda a través de una amplia oferta de actividades relacionadas con el patrimonio.

\section{La región del Alt Pirineu i Aran y su vocación turística}

La región de montaña del Alt Pirineu i Aran, situada en el cuadrante noroccidental de Cataluña, está integrada por las comarcas de la Alta Ribagorça, Pallars Sobirà, Pallars Jussà, Alt Urgell, Cerdanya y el territorio del Aran. Se trata de una región que, debido a su notable marginalidad geográfica, presentó a lo largo del siglo XX considerables dificultades para lograr, por si misma, una dinamización económica suficiente como para mejorar las rentas de sus pobladores y fijarlos en el territorio. La escasa presión humana y las actividades agropecuarias extensivas tradicionales desarrolladas en la zona permitieron mantener y conservar un patrimonio natural y cultural de innegable valor y atractivo que, con el paso del tiempo, se convertirá en su principal recurso económico ${ }^{38}$.

En la cordillera pirenaica, la presencia del fenómeno turístico se remonta a finales del siglo XIX con la práctica, por parte de colectivos minoritarios, de actividades como el excursionismo, el termalismo y el alpinismo. El turismo masivo no surge hasta mediados del siglo XX con la apertura de las primeras estaciones de esquí alpino. Este, como actividad turística moderna, representa -en términos absolutos- la tipología con mayor impacto social, económico y territorial en la zona ${ }^{39}$. Así lo reflejan las estadísticas a escala local, que evidencian el repunte de la población (figura 1), el crecimiento del PIB y la renta per cápita o el importante incremento de la oferta hotelera y del parque de viviendas secundarias. Las estaciones de esquí alpino actúan como verdaderos motores económicos para el territorio ya que generan numerosos puestos de trabajo, directos e indirectos, y una intensa actividad en el sector inmobiliario asociada a procesos especulativos de índole urbanística. Durante los años ochenta y noventa, el turismo de nieve se consolida y se populariza en amplios segmentos de la población y, con la apertura de nuevas estaciones de invierno, los valles pirenaicos ven en el esquí una oportunidad para dinamizar sus territorios y frenar la sangría demográfica.

Pese a la primacía del turismo de nieve (evidenciado por la mayor capacidad de alojamiento turístico y recaudación del impuesto sobre estancias en establecimientos turísticos (IEET) ${ }^{40}$ en los municipios asociados a dicha modalidad), el mer

37 Cànoves, 2004.

38 Gómez et al., 2016

39 López-Palomeque, 2009.

40 En el año 2015, las mayores cifras de recaudación del impuesto sobre estancias en establecimientos turísticos (IEET) se registraron en aquellos municipios turísticos situados en el área de influencia directa de los grandes dominios esquiables: Naut Aran y Vielha e Mijaran, relacionados con la estación de esquí de Baqueira-Beret; Puigcerdà y Alp, relacionados con las 


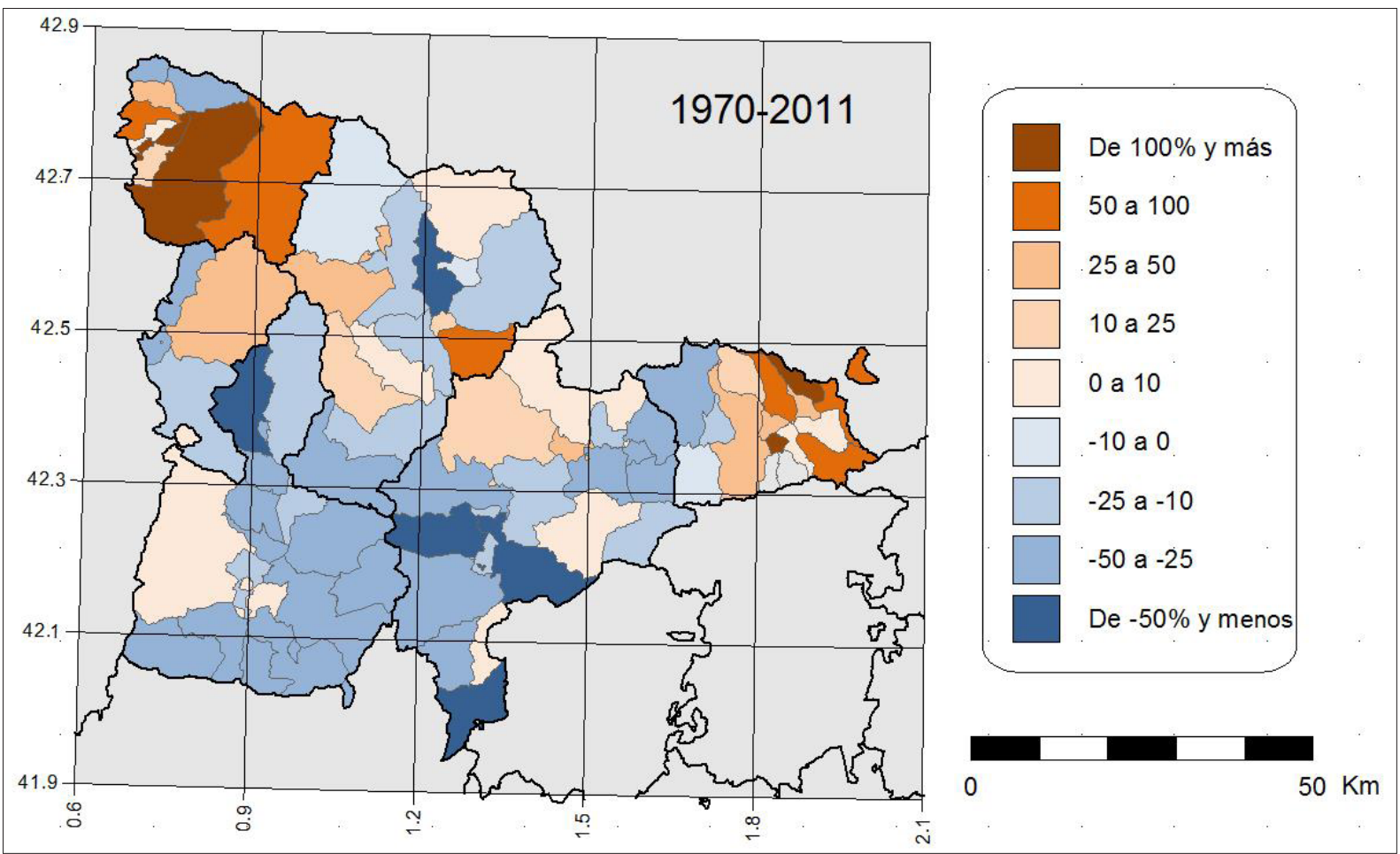

Figura 1. Evolución porcentual de la población de hecho en la región del Alt Pirineu i Aran (19702011)

Fuente: Elaboración propia a partir de datos procedentes del Institut d’Estadística de Catalunya y bases cartográficas procedentes del Institut Cartogràfic i Geològic de Catalunya.

cado turístico actual, muy globalizado y accesible, reclama nuevos productos. Con el objetivo de situar los espacios de montaña en el mapa de los destinos turísticos, se constata la necesidad de diversificar y ampliar la oferta turística con nuevos productos, dando así respuesta a las nuevas exigencias de la demanda ${ }^{41}$. En realidad, dicha tendencia ya empieza a manifestarse en la vertiente española de los Pirineos a partir de los años ochenta, con la irrupción de los deportes de aventura (descenso de barrancos y aguas bravas) introducidos por el público francés; y se consolida a lo largo de los noventa y años 2000, con el auge de los establecimientos de turismo rural, el senderismo y el turismo cultural. El proceso de patrimonialización territorial de los Pirineos se activa, abriendo el foco de interés turístico a una amplia gama de recursos naturales y culturales existentes en la región. Lo que en sus inicios fue la protección de aquellos espacios naturales más emblemáticos y espectaculares desde el punto de vista paisajístico (como, por ejemplo, el Parque Nacional de Aigüestortes i Estany de Sant Maurici -1956-, y más tarde el Parque Natural del Cadí-Moixeró -1983- y el Parque Natural de l'Alt Pirineu -2003-), se traslada, de igual modo, al patrimonio cultural con la protección de monumentos y la recuperación de la memoria histórica.

El incremento y la diversificación de la oferta turística y el aumento de los flujos turísticos, especialmente en períodos vacacionales y fines de semana, comporta estaciones de esquí de La Molina y Masella; y la Vall de Boí, relacionado con la estación de esquí de Boí-Taüll Resort.

41 Font, 2012. 
un mayor grado de desestacionalización de la actividad y una expansión territorial del fenómeno turístico. A pesar de todo, van a continuar siendo las comarcas relacionadas con el turismo de nieve (Aran, Alta Ribagorça, Pallars Sobirà y Cerdanya) las que presenten los mayores índices de desarrollo y especialización turística, con una amplia oferta de alojamientos turísticos y unas elevadas tasas de funcionalidad turística (tabla 2).

Tabla 2. Dimensión territorial del turismo en la región del Alt Pirineu i Aran a partir de la distribución comarcal de la oferta de alojamientos turísticos y la dimensión de las estaciones de esquí, 2015.

\begin{tabular}{|c|c|c|c|c|c|c|c|c|c|c|}
\hline \multirow[t]{2}{*}{ Comarca } & \multirow[t]{2}{*}{$\begin{array}{c}\text { Población } \\
(2015)\end{array}$} & \multirow[t]{2}{*}{$\begin{array}{c}\mathrm{N}^{\circ} \text { de } \\
\text { plazas de } \\
\text { alojamiento } \\
\text { turístico } \\
\text { regladas } \\
(2015)\end{array}$} & \multirow[t]{2}{*}{$\begin{array}{l}\text { Tasa de } \\
\text { función } \\
\text { turística }\end{array}$} & \multirow[t]{2}{*}{$\begin{array}{c}\text { Viviendas } \\
\text { de usos } \\
\text { turístico } \\
(2015)\end{array}$} & \multicolumn{2}{|c|}{$\begin{array}{c}\text { Viviendas } \\
\text { secundarias } \\
(2011)\end{array}$} & & staciones & de es & rdico \\
\hline & & & & & $\mathbf{n}^{\mathbf{o}}$ & $\begin{array}{l}\text { \% sobre } \\
\text { el total de } \\
\text { viviendas }\end{array}$ & $\mathbf{n}^{\mathbf{o}}$ & $\begin{array}{l}\text { Capa- } \\
\text { cidad } \\
\text { acumu- } \\
\text { lada en } \\
\text { esquia- } \\
\text { dores / } 1 \\
\text { hora }\end{array}$ & $n^{o}$ & $\mathbf{K m}$ \\
\hline Alt Urgell & 20.695 & 4.724 & 22,83 & 84 & 2.640 & 18,67 & - & - & 2 & 58,3 \\
\hline $\begin{array}{l}\text { Alta } \\
\text { Ribagorça }\end{array}$ & 3.884 & 3.358 & 86,46 & 236 & 1.881 & 43,51 & 1 & 15.850 & - & - \\
\hline Aran & 9.926 & 9.657 & 97,29 & 569 & 5.446 & 5.446 & 1 & 60.203 & - & 7 \\
\hline Cerdanya & 17.870 & 7.916 & 44,30 & 398 & 11.353 & 53,58 & 2 & 43.090 & 3 & 113 \\
\hline $\begin{array}{l}\text { Pallars } \\
\text { Jussà }\end{array}$ & 13.609 & 2.982 & 21,91 & 73 & 3.786 & 34,52 & - & - & - & - \\
\hline $\begin{array}{l}\text { Pollars } \\
\text { Sobirà }\end{array}$ & 7.060 & 11.238 & 159,18 & 297 & 3.397 & 45,27 & 3 & 21.630 & 1 & 59 \\
\hline \multicolumn{11}{|l|}{ Alt } \\
\hline $\begin{array}{l}\text { Pirineu i } \\
\text { Aran }\end{array}$ & 73.044 & 39.875 & 54,59 & 1657 & 28.503 & 41,76 & 7 & 140.773 & 6 & 237,3 \\
\hline
\end{tabular}

Fuente: Elaboración propia a partir de datos procedentes del Institut d'Estadística de Catalunya, de la Guía oficial d'establiments turístics de Catalunya y de ATUDEM.

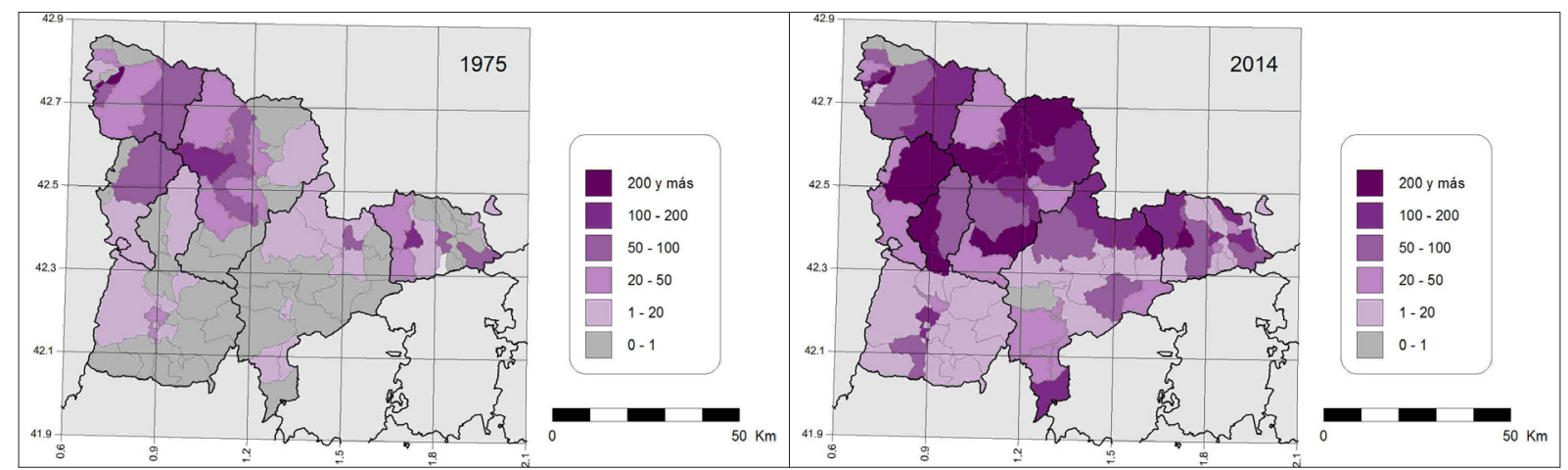

Figura 2. Evolución de la Tasa de Función Turística en la región del Alt Pirineo i Aran (1975 y 2014) Fuente: Elaboración propia a partir de datos procedentes del Institut d'Estadística de Catalunya y bases cartográficas procedentes del Institut Cartogràfic i Geològic de Catalunya. 
En este sentido, desde el año 1975, la funcionalidad turística de la región ha experimentado un gran aumento, con valores actuales en algunos de sus municipios tan solo comparables al de los ámbitos turísticos costeros de sol y playa. De igual modo, la evolución de la tasa de función turística a escala municipal pone de manifiesto la expansión territorial del turismo a lo largo de las tres últimas décadas en la región, evidenciándose una tendencia hacia el "monocultivo" turístico, sobre todo en los municipios de alta montaña de la mitad norte de la región (figura 2).

\section{El patrimonio histórico-artístico, un activo de territorio para el desa- rrollo turístico del Alt Pirineu i Aran}

La multifuncionalidad turística de la montaña, junto a su diversidad y riqueza paisajística, inciden de manera directa en la dinámica del propio sistema turístico, desempeñando el patrimonio cultural un importante papel en las estrategias de diversificación y creación de nuevos productos turísticos. Los recursos turísticos que integran el patrimonio cultural son de naturaleza muy diversa y están relacionados con: a) el legado histórico construido, formado por el conjunto de monumentos y recursos artísticos de un espacio de vieja ocupación, que en los Pirineos estaría representado por el arte románico; b) la arquitectura, el hábitat y el poblamiento tradicional; y c) la recuperación y preservación de la memoria territorial e histórica, de sus tradiciones y cultura, de todos aquellos elementos denominados inmateriales o intangibles del patrimonio ${ }^{42}$.

El patrimonio cultural pirenaico presenta rasgos comunes al patrimonio cultural de otros espacios montañosos europeos: conservación de elementos arquitectónicos milenarios y tradiciones centenarias que han sobrevivido al paso del tiempo. Desde la Administración Pública, a través de los distintos instrumentos de planificación territorial y urbanística, los elementos patrimoniales del territorio son considerados cada vez más como un activo para el desarrollo económico y social a nivel local, que hay que preservar y potenciar. El interés y la sensibilidad hacia el patrimonio que han mostrado los distintos actores implicados en el territorio han logrado, tras años de trabajo colectivo, que la UNESCO reconozca como Patrimonio de la Humanidad las iglesias románicas catalanas de la Vall de Boí (2000) y las fiestas del fuego del solsticio de verano en los Pirineos (2015).

Ahondando en el potencial turístico del patrimonio cultural pirenaico, y centrándonos en los recursos histórico-artísticos presentes en la región del Alt Pirineu i Aran (tabla 3), cabe destacar que en el año 2016 prácticamente un 45 por ciento de los monumentos arquitectónicos de la zona estaban catalogados, bien como "bienes culturales de interés local" (BCIL), bien como "bienes culturales de interés nacional" (BCIN), lo que demuestra el creciente interés y sensibilidad por la protección del patrimonio. Muy a menudo, tanto la catalogación y protección del hito monumental como su instrumentalización con fines turísticos, son procesos paralelos, por lo que

42 Delgado et al., 2003. 
una elevada presencia de elementos monumentales protegidos denota un cambio de mirada hacía el patrimonio (interés por su conocimiento y salvaguarda) al constituir una oportunidad para el desarrollo turístico local.

Del conjunto de comarcas que integran la región pirenaica, se da la paradoja que el territorio más turístico de la zona, el Aran, es el que presentaba en 2016 el porcentaje más bajo de monumentos protegidos, un 27,8 por ciento del total (tabla 3). Este hecho invita a formular la siguiente pregunta: ¿la preeminencia del turismo de nieve en el Valle de Arán releva el patrimonio cultural a un segundo plano, siendo su protección algo no prioritario? Los datos apuntarían hacia esa dirección pero, teniendo en cuenta el elevado número de monumentos y núcleos de población del Aran que actualmente están en trámite de ser declarados bienes culturales de interés nacional, se podría señalar un cambio de tendencia respeto a la consideración del patrimonio cultural y su protección ${ }^{43}$.

Tabla 3. Protección del patrimonio monumental en la región del Alt Pirineu i Aran, 2016

\begin{tabular}{|c|c|c|c|c|c|c|c|c|c|}
\hline \multirow[t]{2}{*}{ Comarca } & \multicolumn{3}{|c|}{ Monumentos } & \multicolumn{3}{|c|}{$\begin{array}{l}\text { Monumentos según } \\
\text { categoria de protección }\end{array}$} & \multicolumn{3}{|c|}{ Monumentos románicos } \\
\hline & total & protegidos & $\begin{array}{c}\% \\
\text { sobre } \\
\text { total }\end{array}$ & $\begin{array}{l}\text { BCIL } \\
\left(n^{\circ}\right)\end{array}$ & $\begin{array}{c}\text { BCIN } \\
\left(n^{0}\right)\end{array}$ & $\begin{array}{l}\text { Incoado- } \\
\text { BCIN }\left(\mathbf{n}^{\circ}\right)\end{array}$ & total & protegidos & $\begin{array}{c}\% \\
\text { sobre } \\
\text { total }\end{array}$ \\
\hline Alt Urgell & 364 & 229 & 62,91 & 190 & 34 & 5 & 104 & 76 & 73,08 \\
\hline $\begin{array}{l}\text { Alta } \\
\text { Ribagorça }\end{array}$ & 208 & 98 & 47,12 & 71 & 27 & - & 33 & 32 & 96,67 \\
\hline Aran & 273 & 76 & 27,84 & 12 & 15 & 49 & 34 & 12 & 35,29 \\
\hline Cerdanya & 276 & 97 & 35,14 & 64 & 32 & 1 & 48 & 36 & 75,00 \\
\hline Pallars Jussà & 496 & 261 & 56,62 & 220 & 41 & - & 84 & 45 & 53,57 \\
\hline $\begin{array}{l}\text { Pallars } \\
\text { Sobirà }\end{array}$ & 331 & 105 & 31,72 & 73 & 32 & - & 82 & 37 & 45,12 \\
\hline $\begin{array}{l}\text { Alt Pirineu i } \\
\text { Aran }\end{array}$ & 1.948 & 866 & 44,46 & 630 & 181 & 55 & 385 & 238 & 61,82 \\
\hline
\end{tabular}

Fuente: Elaboración propia a partir de datos procedentes del Inventari de Patrimoni Arquitectònic de Catalunya.

Aunque el patrimonio es instrumentalizado como recurso de primer orden para el desarrollo económico local de los territorios, los organismos públicos locales y regionales han tomado conciencia de la necesidad de proteger, conservar y promocionar el patrimonio cultural y sus valores ya que forman parte de la identidad colectiva y la memoria histórica de un territorio y una sociedad. Bajo estas circunstancias, los instrumentos de planificación territorial y urbanística de la zona ${ }^{44}$ incorporan -en sus respectivas memorias- inventarios de elementos patrimoniales, directrices sobre los criterios de catalogación y un contenido documental, que van a servir de

43 En 2014, mediante la certificación "Biosphere Destination", se reconoce a la Val d'Aran como un destino sostenible que gestiona de manera responsable toda su actividad turística e invita a poner en valor el patrimonio natural y cultural.

44 Pla Director Urbanístic del Pallars Sobirà, 2008; y Pla Director Urbanístic de la Val d'Aran, 2010. 
base para la elaboración de futuros catálogos de bienes a proteger, que formarán parte de los planes urbanísticos municipales.

\section{El románico, un destacado hito patrimonial}

Dentro del legado histórico, integrado por el conjunto de monumentos que conforman el paisaje, la historia y la identidad pirenaica, está el arte románico, un estilo artístico propio de la Edad Media ( siglos X, XI y XII) que dejó huella en numerosos edificios religiosos, fortalezas y construcciones civiles. El románico se extiende por Centroeuropa, Francia, el norte de Italia, el Reino Unido y el norte de la Península Ibérica. Según Javier Rivera ${ }^{45}$ "un edificio no sólo tiene valor en sí mismo, debido a sus cualidades estéticas, sino también como testigos que corroboran con su presencia material la veracidad de un tiempo, de ciertos hechos históricos, y este edificio constituye un elemento más del paisaje, una herencia recibida de nuestros ancestros". Por tanto, la arquitectura románica constituye un elemento singular de identificación paisajística que, en el caso de estudio, abarca la totalidad de la región, actuando como elemento de cohesión cultural y territorial con unos rasgos propios (románico lombardo). Los edificios religiosos (catedrales, monasterios, iglesias, capillas y ermitas) han sido los principales herederos de este estilo artístico; pero tan característico como las iglesias lo han sido también los castillos, símbolos de la reorganización territorial y del dominio condal durante los siglos XI y XII. Estos, a diferencia de las edificaciones religiosas, han llegado hasta nuestros días en un estado muy precario de conservación debido a su abandono prematuro a partir de los siglos XIV y XV, conservándose, en el mejor de los casos, restos de muralla y torres. Las fortificaciones principales se extienden a lo largo de la franja pre-pirenaica.

La elevada presencia de edificaciones religiosas de época románica en la región del Alt Pirineu i Aran, recogidas en el catálogo del Inventari de Patrimoni Arquitectònic de Catalunya (tabla 3) ${ }^{46}$, y las dimensiones arquitectónicas de alguna de ellas, nos evocan a un pasado repleto de asentamientos humanos cuando la montaña actuaba de espacio refugio en una zona de frontera con el mundo islámico. A finales de la Alta Edad Media, el norte de Cataluña, incluidos los Pirineos, formaba parte de la llamada Marca Hispánica del Imperio Carolingio, un territorio de frontera con los sarracenos, que muy pronto, y con la configuración de los condados ${ }^{47}$, adquiere una autonomía territorial propia. El románico lombardo, es el estilo artístico más carac-

45 Rivera, 2010.

46 El Inventari de Patrimoni Arquitectònic de Catalunya es un instrumento de estudio y difusión de los bienes patrimoniales construidos, que desde el año 1982 incluye edificios y construcciones de interés artístico, arquitectónico o histórico, sectores y elementos de edificios, elementos arquitectónicos aislados, pequeños conjuntos y núcleos de interés histórico-artístico. Dentro del inventario tienen cabida las tres figuras de protección que establece la Ley 9/1993 de patrimonio cultural catalán: 1) los bienes culturales de interés nacional (BCIN), 2) los bienes culturales de interés local (BCIL), y 3) el resto de bienes que forman parte del patrimonio cultural.

47 La actual región del Alt Pirineu i Aran, durante los siglos X y XI la formaban los condados de Cerdanya, Urgell, Pallars y Ribagorça. 
terístico de la zona ${ }^{48}$; y trasciende más allá de su propio interés artístico al estar relacionado, según el ideario nacionalista catalán, con los orígenes y raíces culturales de Cataluña como nación. Ya a finales del siglo XIX, con el despertar de los movimientos románticos y nacionales en toda Europa, entre los círculos nacionalistas ilustrados de la burguesía catalana existió un gran interés por redescubrir el Pirineo y su patrimonio a través del excursionismo ${ }^{49}$. La atención hacia el patrimonio monumental y la preocupación por su conservación condujo a la Mancomunidad de Cataluña a crear en el año 1914 el Servei de Conservació i Catalogació de Monuments de la Mancomunitat de Catalunya; y posteriormente se produjo el traslado y museización de numerosas obras artísticas procedentes de los Pirineos y de otros puntos de Cataluña. Desde entonces, el románico pirenaico, símbolo de un territorio, una época y una sociedad, ha suscitado un especial interés en Cataluña.

Centrándonos de nuevo en el Pirineo occidental catalán, en relación con su patrón histórico de poblamiento, la presencia de un elevado número de núcleos de población surgidos durante la Edad Media tiene su reflejo, a nivel patrimonial, en la existencia de un gran número de monumentos románicos, en su gran mayoría pequeñas iglesias parroquiales, ermitas y capillas, que tejen una densa red de hitos patrimoniales distribuidos a lo largo de toda la región (figura 3). En general, son construcciones modestas, a menudo con importantes modificaciones arquitectónicas a posteriori, que generan un escaso interés turístico, muy acotado al ámbito local. Sin embrago, se trata de un patrimonio monumental relativamente fácil de instrumentalizar como oferta turística complementaria, actuando como elemento de valor añadido para el conjunto del destino turístico y de su imagen, y como símbolo de identidad territorial y paisajística. Tan solo unos pocos monumentos, cuyas características histórico-artísticas avalan su importancia y excepcionalidad, tendrán una dinámica turística propia, que traspasarán el ámbito estrictamente local para ser recursos turísticos de primer orden a escala regional, e incluso estatal. Nos referimos a la catedral de Santa María de la Seu d'Urgell y a su Mueso Episcopal, una obra de estilo románico que refleja la importancia que tuvo la población durante la Edad Media como sede del Condado de Urgell, y al conjunto de iglesias románicas de la Vall de Boí, a las cuales nos referiremos más adelante.

Según muestra el Inventari de Patrimoni Arquitectònic de Catalunya, el potencial turístico del Alt Pirineu i Aran relacionado con el arte románico es elevado ya que cuenta con un total de 375 monumentos distribuidos por todo el territorio (figura 3). El 62 por ciento de los monumentos románicos inventariados están catalogados bajo alguna de las figuras de protección vigentes actualmente: bienes culturales de interés nacional y bienes culturales de interés local. Asimismo, se observa que la cobertura de protección de los monumentos románicos inventariados es mayor al de otros estilos arquitectónicos.

48 Durliat, 1989.

49 Martí-Henneberg, 1994. 


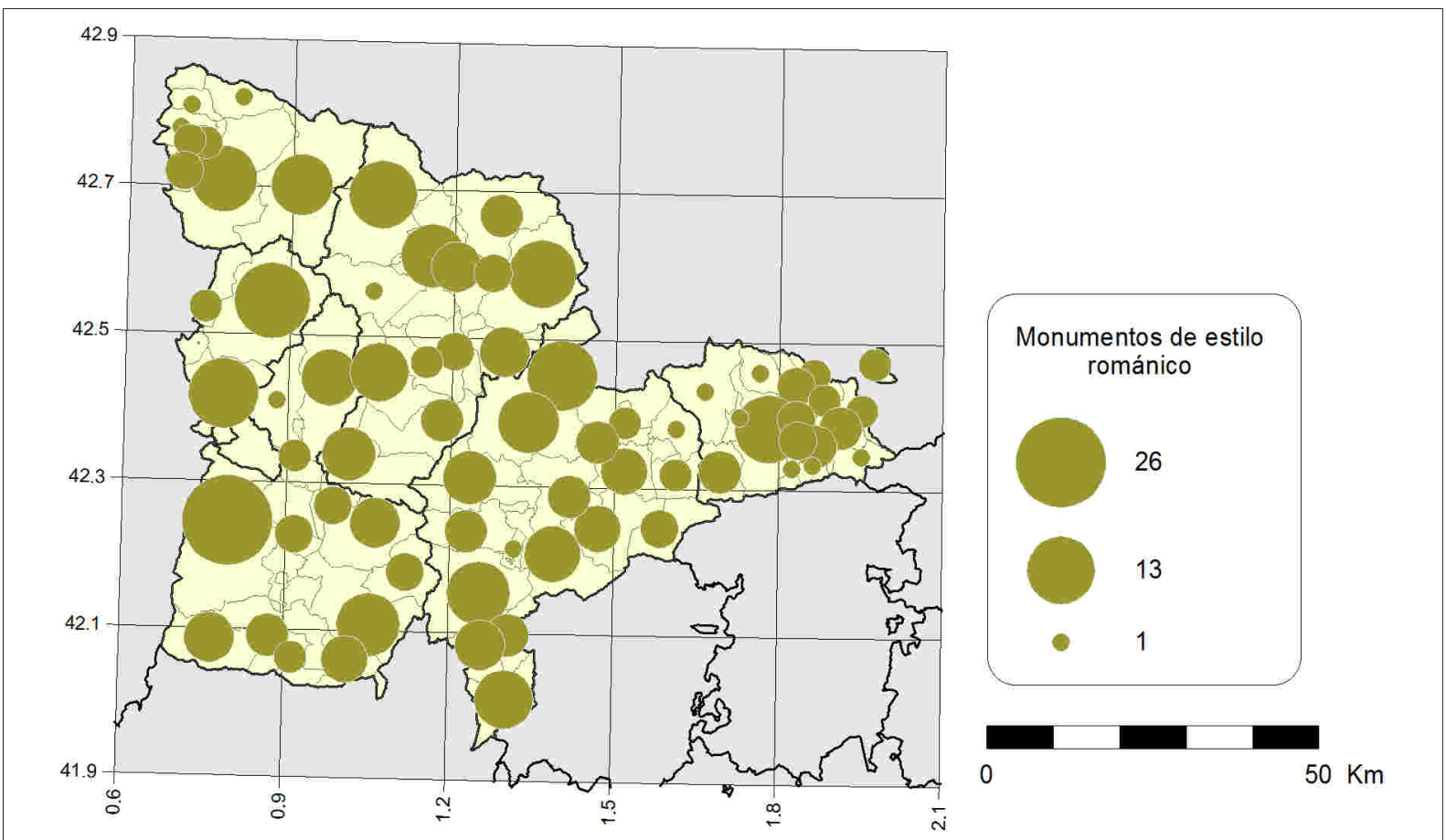

Figura 3. Distribución municipal de los monumentos de estilo románico que forman parte del Inventario de Patrimonio Arquitectónico de Cataluña en la región del Alt Pirineu i Aran, 2016 Fuente: Elaboración propia a partir de datos procedentes del Inventari de Patrimoni Arquitectònic de Catalunya y bases cartográficas procedentes del Institut Cartogràfic i Geològic de Catalunya.

En este mismo sentido, a escala comarcal se aprecian diferencias notables en cuanto a porcentajes totales de protección de monumentos románicos, destacando por encima de las otras la comarca de la Alta Ribagorça, que con un 95 por ciento de los edificios románicos catalogados cubre la casi totalidad de su patrimonio (figura 4). No es un hecho casual que en esta misma comarca se halla el municipio de la Vall de Boí, uno de los principales referentes artísticos del románico catalán.

La mayoría de los monumentos se catalogan y protegen como bienes culturales de interés local (BCIL), y tan solo en aquellos casos cuyas características arquitectónicas y/o históricas del edificio, tanto por singularidad o relevancia, así lo requieran, serán declarados bienes culturales de interés nacional (BCIN). En el año 2016, un total de 62 monumentos románicos del Alt Pirineu i Aran estaban catalogados como bienes culturales de interés nacional (cuadro 6). Desde el punto de vista turístico, los BCINs suelen generar un mayor atractivo e interés de cara al visitante y, en consecuencia, la dimensión turística y territorial de los mismos acostumbra a ser mayor, siendo más compleja su gestión. La distribución territorial de los monumentos románicos catalogados como bienes culturales de interés nacional (BCIN) muestra cierta asimetría, con una concentración espacial en determinados municipios de la región (figura 5). Una vez más, el municipio de la Vall de Boí, con un total de 16 elementos catalogados con el máximo rango, ocupa la primera posición, con la práctica totalidad de su patrimonio arquitectónico protegido. Sin duda, el reconocimiento de las iglesias románicas de la Vall de Boí como Patrimonio de la Humanidad por la UNESCO ha tenido un papel muy importante en todo ese proceso: el patrimonio 
histórico-artístico del valle ha sido catalogado y protegido, incluidos los núcleos urbanos tradicionales con la finalidad de preservar su estructura y edificaciones.

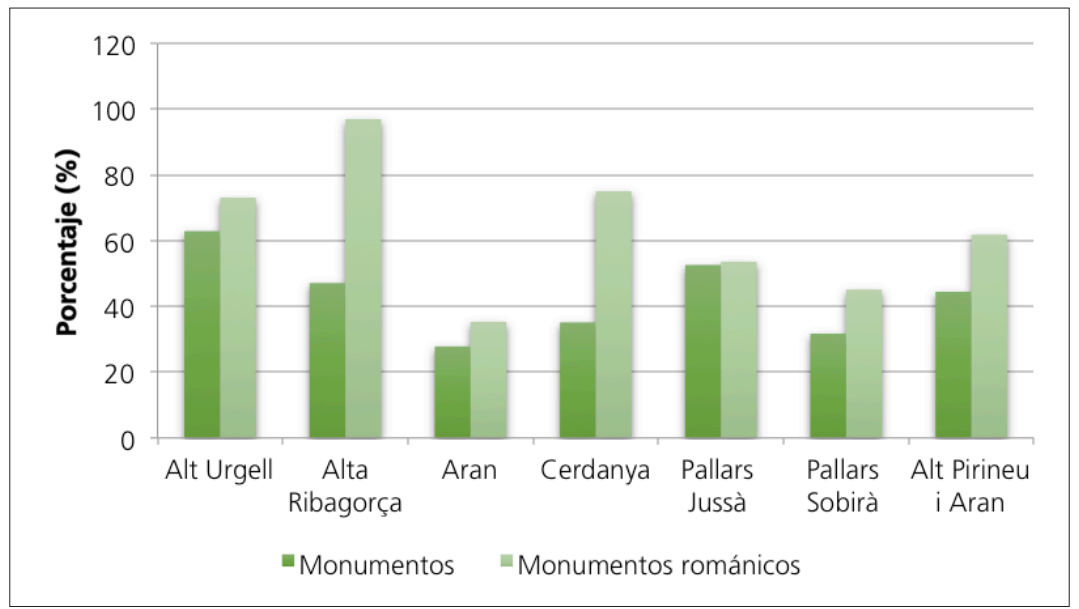

Figura 4. Distribución comarcal y comparativa según porcentaje de protección entre el total de monumentos y monumentos románicos inventariados en la región del Alt Pirineu i Aran, 2016 Fuente: Elaboración propia a partir de datos procedentes del Inventari de Patrimoni Arquitectònic de Catalunya.

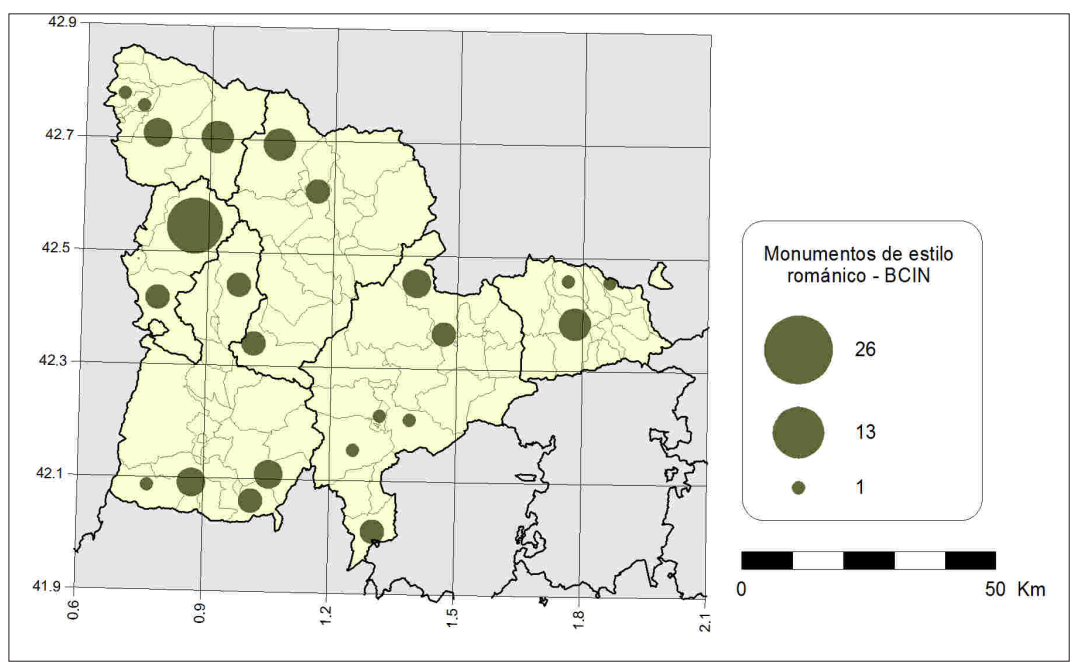

Figura 5. Distribución municipal de los bienes culturales de interés nacional $(B C I N)$ de estilo románico en la región del Alt Pirineu i Aran, 2016

Fuente: Elaboración propia a partir de datos procedentes del Inventari de Patrimoni Arquitectònic de Catalunya y bases cartográficas procedentes del Institut Cartogràfic i Geològic de Catalunya.

\section{Actores y estrategias en la incorporación del patrimonio histórico-ar- tístico al sistema turístico}

Las políticas en materia cultural y turística son sensibles a los denominados procesos de valorización del patrimonio, a la vez que parte implicada en dichos procesos. En zonas rurales y de montaña, la participación de los actores públicos en la restauración de monumentos, la museización de espacios, la creación y señalización de rutas temáticas y las acciones de comunicación, han contribuido, en gran medida, al despliegue y posterior desarrollo del turismo cultural. 
En Cataluña, parte de las políticas públicas relacionadas con la restauración y conservación del patrimonio cultural en zonas de montaña han sido canalizadas a través de los Plans Comarcals de Muntanya ${ }^{50}$, siendo uno de sus objetivos la conservación y restauración del patrimonio histórico y artístico. En las últimas ediciones de los planes comarcales de montaña ha existido un programa específico de actuaciones para la mejora del patrimonio cultural. El gasto total efectuado en actuaciones de mejora de elementos del patrimonio para las ediciones 2001-2005 y 20092012 fue aproximadamente de unos 5 millones de euros, una cifra que no alcanzó el 1 por ciento del gasto total ejecutado para el conjunto de actuaciones en la región. Más allá de las cifras numéricas, a escala local las intervenciones de rehabilitación y conservación del patrimonio revierten de forma positiva y directa sobre el territorio, al convertir el patrimonio cultural en un activo para el desarrollo turístico. Según un análisis detallado del gasto ejecutado por monumentos y comarcas, gran parte de los recursos económicos se han destinado a obras de mejora y restauración de monumentos (figura 6). Las comarcas con un mayor nivel de gasto han sido la Alta Ribagorça y el Pallars Sobirà, relacionadas ambas con la presencia de importantes conjuntos monumentales (Vall de Boí y Valls d’Àneu).

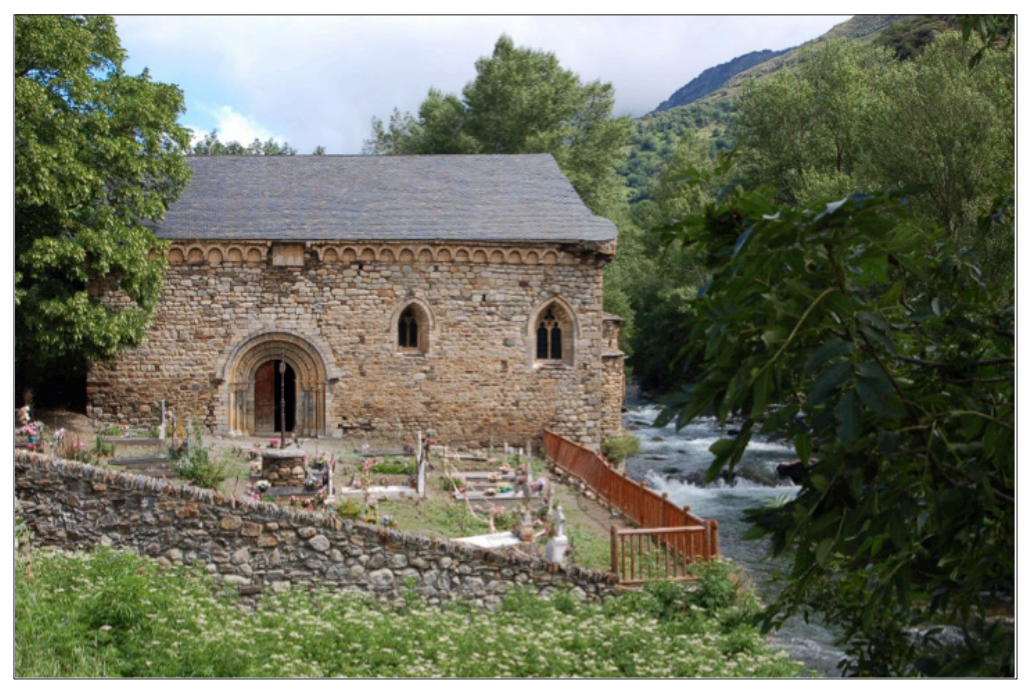

Figura 6. Iglesia románica de Sant Joan d'Isil (siglo XI) - Valls d'Àneu (Pallars Sobirà)

Fuente: Archivo propio.

Debido a la crisis económica de los últimos años, las administraciones acusan una falta notable de recursos que ha dejado en el aire a un número importante de intervenciones programadas de antemano. A la espera de que las arcas públicas se vuelvan a recuperar de nuevo, los fondos de la Unión Europea, principalmente mediante el programa LEADER y sus respectivos grupos de acción local, continúan

50 Los Plans Comarcals de Muntanya, es un instrumento de planificación territorial para cada una de las comarcas de montaña, definidas según la Llei d'Alta Muntanya, aprobada en 1983 por el gobierno autonómico. Las comarcas en cuestión son: Aran, Alta Ribagorça, Alt Urgell, Berguedà, Cerdanya, Garrotxa, Pallars Jussà, Pallars Sobirà, Ripollès y Solsonès. La vigencia de los planes es de 5 años, con 4 ediciones desde el año 1990 hasta el 2012. 
siendo una de las principales vías de financiación, que contribuyen a poner en marcha nuevas iniciativas de desarrollo local y regional relacionadas con el patrimonio. Carmen Delgado et al. ${ }^{51}$ aporta un análisis detallado de las potencialidades del patrimonio cultural para la implantación y promoción del turismo en la montaña de Cantabria, del norte de Palencia y de Burgos, en la que el arte románico se erige como principal elemento identificador del territorio desde el punto de vista cultural. En el artículo se analiza con detalle las distintas políticas públicas llevadas a cabo y, en especial, los distintos programas europeos de desarrollo en la región. Entre ellos, el Programa Leader+ (2000-2006) "País Románico" interterritorial, dedicado a la financiación específica relacionada con el patrimonio, y de gran incidencia en la potencialidad turística de la zona. Uno de los objetivos del Programa LEADER se centra en el románico bajo el enunciado "País románico: destino turístico». Éste se desgrana, a su vez, en nueve sub-proyectos: «Itinerario cultural europeo»; «Ecoruta del país Románico»; "Por el camino verde»; «Mundo Miner»; «Las Edades del Territorio»; "El tren de la cordillera»; «Ruta del arte rupestre»; «Posadas del País Románico»; y «Romantur» dirigidos a la creación de nuevos productos vinculados al patrimonio local, a la concentración de recursos y a la integración de la oferta turística, con una estrategia de marca del territorio como destino de turismo cultural y basada en la imagen del arte románico.

\section{La presencia del patrimonio histórico-artístico en la oferta turística del Alt Piri- neu i Aran}

La presencia del patrimonio cultural, en especial del arte románico, en el ámbito de la comunicación y la promoción turística de la región es notable. En base a la exploración llevada a cabo en distintos portales turísticos del Alt Pirineu i Aran se observa, por parte de los entes responsables en comunicación, un interés en posicionar el patrimonio cultural en un lugar destacado de la oferta turística. A la tradicional imagen de los Pirineos, asociada con la práctica del esquí en invierno y con el turismo activo y de naturaleza en verano, actividades que sin duda continúan ocupando un espacio muy destacado en internet, hay que sumarle todos aquellos recursos y productos relacionadas con el patrimonio cultural, que no están sujetos a la estacionalidad turística ni a las condiciones climático-ambientales.

El patrimonio arquitectónico está presente en la práctica totalidad de páginas web visitadas y nutre buena parte de la oferta de turismo cultural de la zona (tabla 4). Los esfuerzos de las entidades locales se centran en dar visibilidad al amplio catálogo de recursos histórico-artístico existentes en sus respectivos municipios y comarcas, a través de descripciones e imágenes aunque, por lo general se trata de una simple recopilación e inventario de recursos con ausencia de verdaderos productos turísticos integrados. La siguiente tabla muestra la diversidad y cuantía de elementos patrimoniales de tipo histórico, que son utilizados para promocionar el territorio y sus paisajes (tabla 4 ).

51 Delgado et al., 2003, 
Tabla 4. Presencia del patrimonio cultural arquitectónico (recursos y productos) en portales turísticos del Alt Pirineu i Aran

\begin{tabular}{|c|c|c|c|c|c|}
\hline Comarca & Entidad & Ámbito & Marca turística & $\begin{array}{l}\text { Patrimonio cultural: } \\
\text { recursos y productos } \\
\text { histórico-artísticos }\end{array}$ & $\begin{array}{r}\mathrm{N}^{\circ} \\
\text { elementos }\end{array}$ \\
\hline \multirow[t]{2}{*}{ Val d'Aran } & \multirow{2}{*}{$\begin{array}{l}\text { Foment Turisme } \\
\text { Val d'Aran }\end{array}$} & \multirow[t]{2}{*}{ Comarcal } & \multirow{2}{*}{$\begin{array}{l}\text { Val d'Aran, l'escència } \\
\text { dels Pirineus }\end{array}$} & Iglesias & 29 \\
\hline & & & & Pueblos & 37 \\
\hline \multirow{14}{*}{$\begin{array}{l}\text { Pallars } \\
\text { Sobirà }\end{array}$} & \multirow{5}{*}{$\begin{array}{l}\text { Consorci Turisme } \\
\text { Valls d'Àneu }\end{array}$} & \multirow[t]{5}{*}{ Supramunicipal } & \multirow{5}{*}{$\begin{array}{l}\text { Valls d'Àneu, la natura } \\
\text { en estat pur }\end{array}$} & Iglesias & 11 \\
\hline & & & & Ermitas & 5 \\
\hline & & & & Monasterios & 1 \\
\hline & & & & Otros & 7 \\
\hline & & & & Pueblos & 26 \\
\hline & \multirow{2}{*}{$\begin{array}{l}\text { Ecomuseu de les } \\
\text { Valls d'Àneu }\end{array}$} & \multirow[t]{2}{*}{ Supramunicipal } & \multirow[t]{2}{*}{ L'Ecomuseu } & Radiales-Iglesias & 8 \\
\hline & & & & Ruta "Juego de Damas" & 4 \\
\hline & \multirow[t]{3}{*}{$\begin{array}{l}\text { Consell Comarcal } \\
\text { del Pallars Sobirà }\end{array}$} & \multirow[t]{3}{*}{ Comarcal } & \multirow[t]{3}{*}{$\begin{array}{l}\text { Pallars Sobirà, valls de } \\
\text { l'Alt Pirineu }\end{array}$} & $\begin{array}{l}\text { Ermitas, puentes } \\
\text { romànicos y santuarios }\end{array}$ & 17 \\
\hline & & & & Pueblos pintorescos & 7 \\
\hline & & & & $\begin{array}{l}\text { Castillos, despoblados y } \\
\text { torres de vigia }\end{array}$ & 5 \\
\hline & \multirow{2}{*}{$\begin{array}{l}\text { Vallferrera } \\
\text { Turisme }\end{array}$} & \multirow[t]{2}{*}{ Municipal } & \multirow{2}{*}{$\begin{array}{l}\text { Vallferera, aquí espot } \\
\text { escoltar el silenci }\end{array}$} & Iglesias y ermitas & 21 \\
\hline & & & & Pueblos & 7 \\
\hline & \multirow{2}{*}{$\begin{array}{l}\text { Ajuntament de } \\
\text { Sort }\end{array}$} & \multirow[t]{2}{*}{ Supramunicipal } & \multirow{2}{*}{$\begin{array}{l}\text { La Vall d'Asua i el } \\
\text { Batlliu, un paisatge de } \\
\text { novel.la }\end{array}$} & Pueblos - Vall d'Assua & 9 \\
\hline & & & & Pueblos - El Batlliu & 7 \\
\hline \multirow{4}{*}{$\begin{array}{l}\text { Alta } \\
\text { Ribagorça }\end{array}$} & \multirow{2}{*}{$\begin{array}{l}\text { Patronat de la Vall } \\
\text { de Boí }\end{array}$} & \multirow[t]{2}{*}{ Municipal } & \multirow{2}{*}{$\begin{array}{l}\text { Vall de Boí, on els } \\
\text { Pirineus toquen el cel }\end{array}$} & Centro del Románico & 1 \\
\hline & & & & $\begin{array}{l}\text { Iglesias Patrimonio de } \\
\text { la Humanidad }\end{array}$ & 9 \\
\hline & \multirow{2}{*}{$\begin{array}{l}\text { Patronat Comarcal } \\
\text { de TurismE de } \\
\text { l'Alta Ribagorça }\end{array}$} & \multirow[t]{2}{*}{ Comarcal } & \multirow{2}{*}{$\begin{array}{l}\text { Alta Ribagorça, } \\
\text { Patronato Comarcal de } \\
\text { Turisme }\end{array}$} & Rutas del románico & 14 \\
\hline & & & & $\begin{array}{l}\text { Iglesias Patrimonio de } \\
\text { la Humanidad }\end{array}$ & 9 \\
\hline \multirow[t]{4}{*}{$\begin{array}{l}\text { Pallars } \\
\text { Jussà }\end{array}$} & $\begin{array}{l}\text { Ajuntament de la } \\
\text { Torre de Capdella }\end{array}$ & Municipal & \multirow{4}{*}{$\begin{array}{l}\text { Vall fosca, l'energia dels } \\
\text { Pirineus } \\
\text { Pallars Jussà, viatge als } \\
\text { orígens }\end{array}$} & Pueblos & 19 \\
\hline & \multirow{3}{*}{$\begin{array}{l}\text { Consell Comarcal } \\
\text { del Pallars Jussà }\end{array}$} & Comarcal & & Iglesias románicas & 12 \\
\hline & & & & Castillos de frontera & 15 \\
\hline & & & & Pueblos con encanto & 5 \\
\hline Alt Urgell & Turisme de La Seu, & Supramunicipal & La Seu d'Urgell, el cor & “Vía Románica” & 53 \\
\hline & & & & $\begin{array}{l}\text { La Seu medieval- } \\
\text { Catedral }\end{array}$ & 1 \\
\hline & & & & La Seu medieval-museo & 1 \\
\hline Cerdanya & $\begin{array}{l}\text { Patronat comarcal } \\
\text { de turisme de la } \\
\text { Cerdanya }\end{array}$ & Comarcal & $\begin{array}{l}\text { Cerdanya, Benvingut } \\
\text { al portal turístic de la } \\
\text { Cerdanya }\end{array}$ & “Vía Románica” & 65 \\
\hline & $\begin{array}{l}\text { Espai d'Iniciatives } \\
\text { del Baridà }\end{array}$ & Supramunicipal & El Baridà & $\begin{array}{l}\text { Románico y patrimonio } \\
\text { Rural }\end{array}$ & 5 \\
\hline $\begin{array}{l}\text { Conjunto } \\
\text { de } \\
\text { comarcas }\end{array}$ & $\begin{array}{l}\text { Generalitat de } \\
\text { Catalunya }\end{array}$ & Supracomarcal & $\begin{array}{l}\text { Pirineu Comtal. Rutes } \\
\text { del naixement de } \\
\text { Catalunya }\end{array}$ & $\begin{array}{l}\text { Itinerarios de } \\
\text { larga distancia y } \\
\text { locales que unen } \\
\text { distintos elementos } \\
\text { patrimoniales }\end{array}$ & 19 \\
\hline
\end{tabular}

Fuente: Elaboración propia a partir de la consulta de los distintos portales turísticos en internet.

Itinerarios turísticos, la estrategia para posicionar el patrimonio cultural en el mercado turístico

El diseño y creación de itinerarios o rutas temáticas es uno de los instrumentos más utilizados para la promoción de los recursos patrimoniales y su integración al 
sistema turístico, ya que de manera aislada la mayoría de elementos patrimoniales difícilmente podrían ser posicionados en un mercado turístico cada vez más globalizado y competitivo. En los últimos años, se ha producido un notable incremento de rutas e itinerarios de índole diversa que pretenden atraer a los turistas potenciales y promocionar el territorio en todo su conjunto y que, bajo un denominador común, tratan de conducir a los visitantes siguiendo un recorrido definido ${ }^{52}$. Para el turismo cultural, el diseño de rutas relacionadas con la memoria histórica, la tradición y el patrimonio histórico-artístico se inserta en la expansión social del patrimonio y en la búsqueda de la autenticidad cultural. Pero pese a la existencia de un gran número de itinerarios y rutas turísticas, no todas ellas consiguen generar las sinergias suficientes para el desarrollo local. Para que ello sea posible no basta con una simple suma de recursos turísticos unidos entre sí por un itinerario sino que el propio itinerario debe convertirse en un verdadero producto turístico implicando a la iniciativa privada.

Los Pirineos no son ajenos a estas dinámicas y como espacio rural de montaña, con un turismo de carácter más bien difuso y de baja intensidad, la oferta de rutas e itinerarios turísticos es muy amplia, con una clara apuesta por el senderismo ${ }^{53}$. De igual modo, las rutas e itinerarios temáticos relacionados con los hitos patrimoniales y el contexto histórico han experimentado un fuerte auge en los últimos años, siendo el arte románico el gran protagonista y común denominador de las rutas.

A escala regional destaca la Ruta Pirineo Condal ${ }^{54}$, creada por la Generalitat de Catalunya en el año 2009 para impulsar el turismo cultural a partir del legado histórico y artístico relacionado con una época muy concreta: la Cataluña medieval de los condados. Bajo la marca Pirineo Condal. Rutas del nacimiento de Cataluña se establecen dos rutas paralelas, una por el norte, a lo largo del Pirineo, y otra por el sur, a lo largo del Pre-pirineo, que cruzan de este a oeste un total de 14 comarcas. Estos dos itinerarios de larga distancia, que actúan como nexo de unión de los principales hitos románicos de Cataluña, incorporan la vertiente histórica y se complementan a escala comarcal con otros itinerarios secundarios de corto recorrido. En el Alt Pirineu i Aran, los monumentos mejor posicionados de la ruta que actúan como nodos turísticos de sus respectivos territorios son la catedral de la Seu d'Urgell, en la comarca del Alt Urgell, y la iglesia de Sant Climent de Taüll, en la comarca de la Alta Ribagorça. Otros enclaves monumentales menores de la ruta son: el antiguo monasterio benedictino de Sant Pere del Burgal (Pallars Sobirà), el castillo y antiguo

52 Hernández, 2011; Molina et al., 2014.

53 Pla estratègic de senderisme de l'Alt Pirineu i Aran.

54 La ruta Pirineo Condal tienen como objetivos: a) identificar y poner en valor los recursos turísticos tangibles e intangibles que identifican al territorio y lo singularizan con respeto a otras destinaciones turísticas en materia de turismo cultural; b) crear una oferta turística integrada, potente, competitiva y sostenible en el Pirineo; y c) poner en valor los principales recursos turísticos asociados a los orígenes medievales de Catalunya, capaz de interesar a los mercados emergentes del turismo cultural. La imagen del logo se compone de un rostro asociado a los condes, una estética que se inspira en la escultura románica y una tipografía de inspiración medieval. 
monasterio de Santa Maria de Mur (Pallars Jussà) y la iglesia de Santa Maria d'Arties (Aran).

A escala local, han surgido otras iniciativas similares con el objetivo de promocionar el patrimonio y relacionarlo con hechos históricos, ya que transmiten mayor autenticidad y experiencia vivencial al turista. La ruta creada recientemente por el Ecomuseu de les Valls d'Àneu (Pallars Sobirà) llamada Juego de Damas, está pensada bajo estos criterios y consiste en un itinerario con visión integral y de género, con el objetivo de poner en valor la historia y el patrimonio construido de las comarcas del Pallars Sobirà y Pallars Jussà mediante la unión de cuatro antiguos monasterios relacionados con personajes históricos femeninos de la Edad Media ${ }^{55}$. La oferta de actividades del Ecomuseu de les Valls d'Aneu se amplía, de igual modo, a otros monumentos románicos y enclaves histórico-culturales de la zona, las denominadas antenas "radiales" 56 , cumpliendo así con una de sus principales funciones, la de poner en valor el patrimonio cultural del valle, incorporando la territorialidad como eje central y vertebrador del proyecto.

El Ecomuseu de les Valls d'Àneu, que inició su actividad a mediados de los noventa, imitando a otras iniciativas similares surgidas en Europa, con el objetivo de valorar el patrimonio cultural local y difundir una nueva cultura del territorio es actualmente uno de los principales referentes turísticos de la población de Esterri d'Àneu, en el Pallars Sobirà. Desde el año 1998 hasta el 2015, la media anual de visitantes que recibe el Ecomuseu se sitúa en torno a los 25.000; y Casa Gassia, sede del Ecomuseu, acoge a la gran mayoría de ellos, con una media anual en los últimos dieciocho años de 17.700 visitas (figura 7). Por otro lado, el número total de visitantes a los hitos patrimoniales distribuidos por el territorio (radiales) se situó cerca de los 5.000 en 2015, con una leve tendencia al alza en los últimos años. Otro de los aspectos significativos a comentar es la marcada estacionalidad turística, puesta de manifiesto en la elevada concentración y afluencia de visitantes durante el mes de agosto (cuadro 5 y figura 8). A pesar de que el disfrute del patrimonio cultural no esté sujeto ni a las inclemencias meteorológicas ni a las grandes inversiones en infraestructuras, sí que se ve muy condicionado por los flujos estacionales en montaña y, en este caso, por la presencia de turistas durante los meses de verano. Sin embargo, el mínimo otoñal e invernal de visitantes al ecomuseo deja entrever una escasa relación con el turismo de nieve, también presente en la zona, pese a la promoción del patrimonio cultural como actividad "après-ski" desde las mismas estaciones (Baqueira-Beret, Espot y Portainé). Una complementariedad, la del turismo cultural, que sí parece establecerse con otras modalidades turísticas vinculadas al patrimonio natural. El turismo cultural y el turismo activo y/o de naturaleza comparten aspectos comunes,

55 La ruta Juego de Damas incorpora los antiguos monasterios de Santa Maria d'Àneu, Sant Pere del Burgal, Santa Maria de Gerri, y castillo y canónica de Santa Maria de Mur.

56 Forman parte de las denominadas antenas radiales, las iglesias románicas de Sant Joan d'Isil, Sant Julià d'Unarre, Sant Pere de Sorpe, Sant Pere del Burgal y Santa Maria d'Àneu, el conjunto monumental románico de Son, la serrería de Alós, la quesería la Roseta de Gavàs, el castillo de València d'Àneu, y los bunkers de la Guingueta d'Àneu. 
como por ejemplo la estacionalidad, la puesta en valor del patrimonio y la sostenibilidad. Se podría concluir pues que la fortaleza de este territorio, conocido como el Alt Pallars, reside en el mantenimiento de su autenticidad e historia, ya que la conservación y revalorización de su patrimonio no obstaculiza ninguna de las actividades turísticas mencionadas hasta ahora y revaloriza el territorio en su conjunto ${ }^{57}$.

Tabla 5. Distribución mensual del número de visitas guiadas a monumentos románicos integrados al Ecomuseu de les Valls d'Àneu en 2015

\begin{tabular}{|c|c|c|c|c|c|c|c|c|c|c|c|c|c|c|c|}
\hline \multirow[t]{2}{*}{ Radiales } & \multicolumn{13}{|c|}{ Visitas - año 2015} & \multicolumn{2}{|c|}{$\begin{array}{c}\text { Media de } \\
\text { visitas } \\
\text { anuales }\end{array}$} \\
\hline & G & $\mathrm{F}$ & M & A & M & $\mathrm{J}$ & $\mathrm{J}$ & $\mathrm{A}$ & $S$ & $\mathrm{O}$ & $\mathrm{N}$ & $\mathrm{D}$ & Total & $\begin{array}{r}2011- \\
2015\end{array}$ & $\begin{array}{r}1998- \\
2015\end{array}$ \\
\hline $\begin{array}{l}\text { Sant Pere del } \\
\text { Burgal }\end{array}$ & 21 & 12 & 23 & 28 & 12 & 16 & 23 & 199 & 6 & 41 & - & 31 & 412 & 370 & 429 \\
\hline $\begin{array}{l}\text { Santa Maria } \\
\text { d'Aneu }\end{array}$ & 12 & 4 & 8 & 28 & - & 35 & 13 & 302 & 6 & 34 & - & 11 & 453 & 248 & 330 \\
\hline $\begin{array}{l}\text { Conjunto } \\
\text { monumental } \\
\text { de Son }\end{array}$ & - & - & - & 8 & - & - & 77 & 1.955 & - & - & - & 23 & 2.063 & 1.850 & 1.405 \\
\hline $\begin{array}{l}\text { Sant Joan } \\
\text { d'Isil }\end{array}$ & - & - & 9 & - & - & 28 & 8 & 635 & 43 & - & - & - & 723 & 686 & 450 \\
\hline $\begin{array}{l}\text { Sant Pere de } \\
\text { Sorpe }\end{array}$ & - & - & 4 & 28 & - & 26 & 27 & 191 & 6 & - & - & 16 & 298 & 170 & 125 \\
\hline Total & 33 & 16 & 44 & 92 & 12 & 105 & 148 & 3.282 & 61 & 75 & $\mathbf{0}$ & 81 & 3.949 & 3.324 & 2.739 \\
\hline
\end{tabular}

Fuente: elaboración propia a partir de los datos facilitados por el Ecomuseu de les Valls d'Aneu

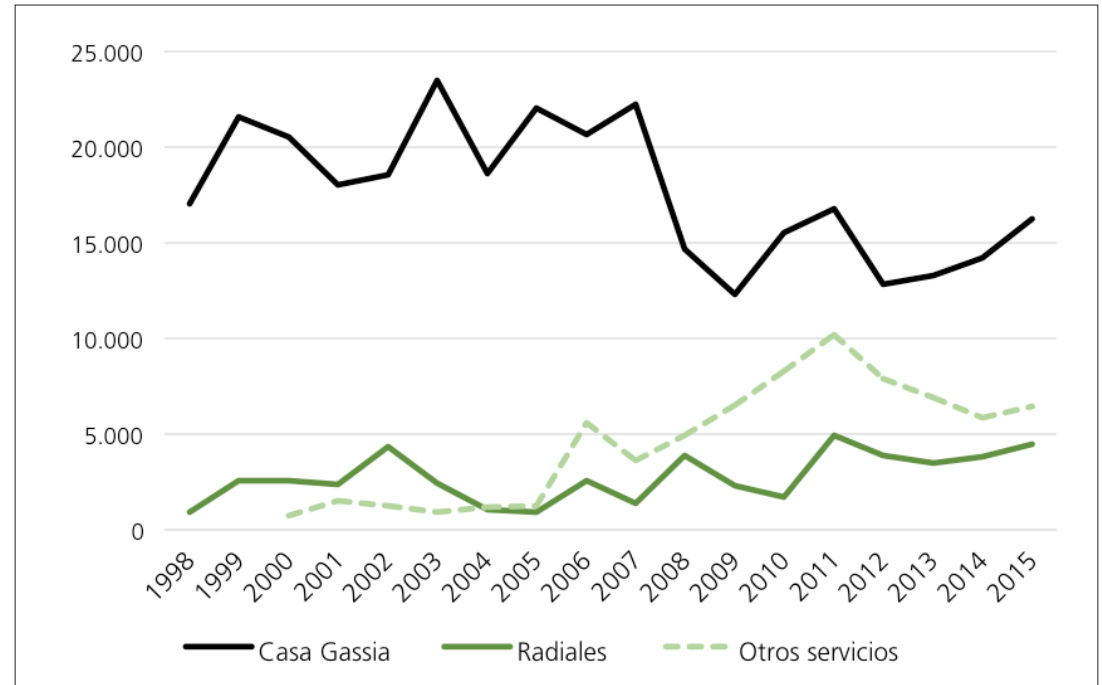

Figura 7. Evolución del número de visitantes al Ecomuseu de les Valls d'Àneu según tipología de visita (1998-2015)

Fuente: elaboración propia a partir de los datos facilitados por el Ecomuseu de les Valls d'Aneu.

Para finalizar este apartado, mencionamos brevemente las acciones llevadas a cabo en relación a la identificación y promoción de recursos patrimoniales de la región a partir de una marca o label. En este sentido, la Via románica es un referente en

57 Jiménez, 2003. 
la promoción patrimonial del arte románico en el Pirineo oriental, que identifica los recursos arquitectónicos de este estilo presentes en la zona. Se trata de un proyecto transfronterizo, que une Perpiñán (Francia) con el extremo sur de la comarca del Alt Urgell a través de las comarcas del Roselló, el Conflent, la Cerdanya y el Alt Urgell. Las actuaciones se han centrado en identificar, señalizar y promocionar el conjunto de iglesias y ermitas románicas presentes en cada una de las cuatro comarcas bajo la marca Vía románica. El término, más allá de una simple etiqueta, identifica un espacio que durante la Edad Media fue una de las principales vías de comunicación entre la costa mediterránea y el interior de la península ibérica (depresión del Ebro), aprovechando la fosa tectónica intra-pireniaca del Conflent-Cerdanya-Urgellet. La vía unía dos de los principales referentes culturales e históricos de la época: la ya mencionada catedral de la Seu d'Urgell y el monasterio de Sant Miquel de Cuixà, actualmente en Francia. Pese al atractivo de la marca, dada la gran cantidad de monumentos románicos presentes en el territorio, la mayoría de ellos son edificaciones rurales modestas, por lo que el interés y valor turístico del monumento radica más en el marco paisajístico en el que se integra que no en sus propios atributos artísticos.

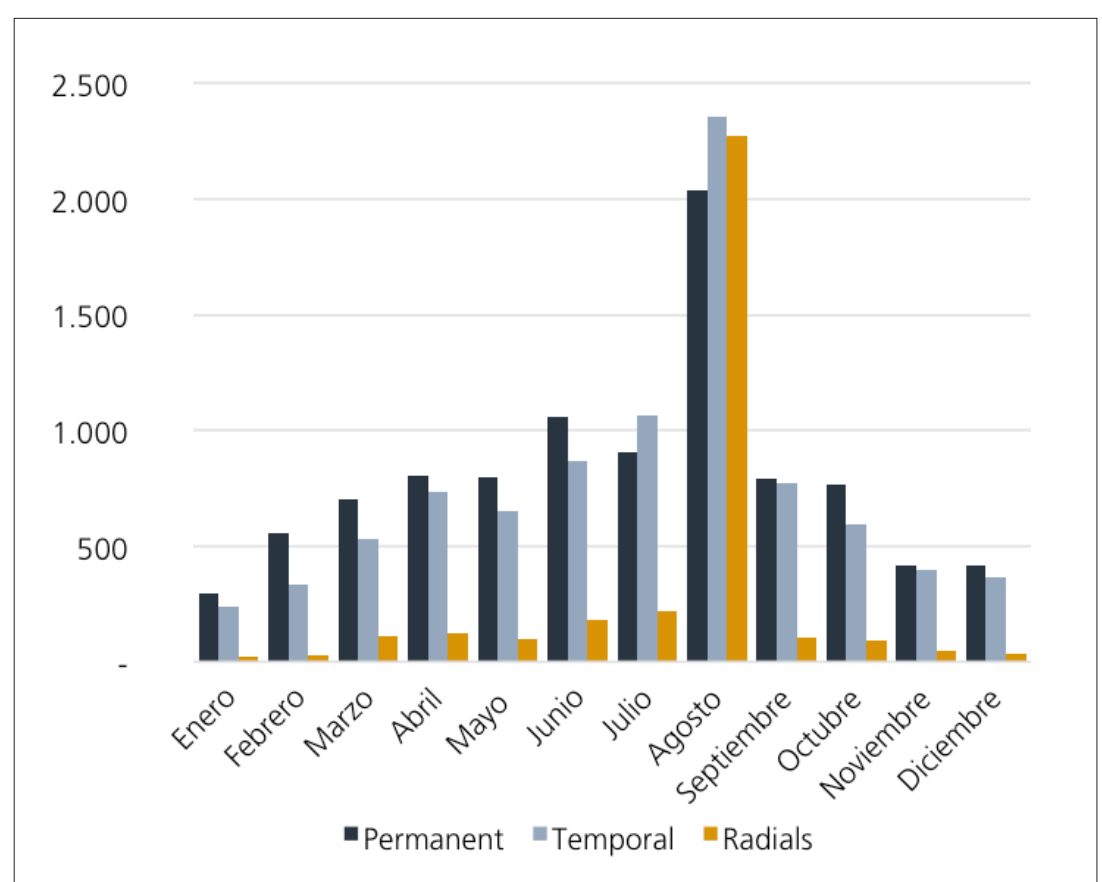

Figura 8. Distribución media mensual del número de visitantes al Ecomuseu de les Valls d'Àneu según tipología de visita (1998-2015) Fuente: elaboración propia a partir de los datos facilitados por el Ecomuseu de les Valls d'Aneu.

\section{La Vall de Boí, románico y turismo en el corazón de los Pirineos}

En el extremo nororiental de la comarca de la Alta Ribagorça, en plena cordillera pirenaica, se sitúa la Vall de Boí, un municipio de alta montaña con una altitud media sobre el nivel del mar superior a los $1.500 \mathrm{~m}$. El río Noguera de Tor, afluente de la Noguera Ribagorçana, vertebra el valle de nordeste a sudoeste. En el tercio norte del 
municipio, está el Parque Nacional de Aigüestortes i Estany de Sant Maurici, uno de los espacios naturales más concurridos durante el verano, con un total de 146.343 entradas al parque por el sector de Boí en el año 2015. En la zona oriental del municipio, y fuera del área de protección, se extiende el dominio esquiable de Boí Taüll, la estación de esquí situada a mayor altitud de los Pirineos catalanes (2.020 - $2.751 \mathrm{~m}$ ), y que durante la temporada 2015-2016 vendió alrededor de unos 120.000 forfaits.

La inauguración de la estación de esquí en el año 1986 supuso la mayor transformación urbanística y turística de la zona, con la creación de un pueblo de nueva planta (Pla de l'Ermita) en las inmediaciones de las pistas, no exento de polémica en aquella época ${ }^{58}$. En la actualidad, la presión turística sobre la Vall de Boí es considerable, ya que el municipio contaba con una oferta de alojamiento turístico de 3.630 plazas en 2015 por una población residente de poco más de 1.000 habitantes.

El elemento singular y de mayor trascendencia turística de la Vall de Boí es su patrimonio histórico-artístico, reconocido internacionalmente por la UNESCO en el 2000. En ese año, un total de nueve iglesias románicas del municipio fueron declaradas Patrimonio de la Humanidad: la Asunción de Cóll, Santa Maria de Cardet, Sant Feliu de Barruera, Santa Eulalia de Erill la Vall, Sant Joan de Boí, Sant Climent de Taüll, Santa Maria de Taüll, la Natividad de Durro y Sant Quirc de Durro. El románico obtenía así su máxima etiqueta para realzarlo y promocionarlo de cara al exterior ${ }^{59}$, convirtiéndose en un referente turístico para la zona. Se trata de un reconocimiento al simbolismo y a la excepcionalidad y monumentalidad arquitectónica de algunas de sus iglesias: edificios con torres (campanarios) de planta cuadrada alzadas a gran altura (Sant Climent de Taüll y Santa Eulàlia de Erill la Vall); sin olvidar el trabajo previo realizado desde las instituciones para conseguir dicho objetivo. Otro elemento de gran valor artístico, son los frescos pictóricos que decoraban por completo el interior de los edificios y que, a principios del siglo XX, fueron trasladadas a Barcelona por la Junta de Museos de Catalunya. Las pinturas murales románicas están actualmente depositadas en el Museo Nacional de Arte de Cataluña (MNAC), siendo una de sus obras de referencia el pantocrátor de Sant Climent de Taüll.

Tras el reconocimiento internacional del románico, su valor y dimensión turística aumentó considerablemente, y se convirtió en un icono del turismo cultural en la zona. A escala local, son varias las actuaciones y repercusiones derivadas de la nueva marca mundial: a) creación del Centro del Románico en la población de Erill la Vall; b) adecuación de las iglesias a su nueva funcionalidad turística (rehabilitación, señalización y museización de espacios); c) incremento del número de empresas del sector servicios (comercio, restauración, alojamientos, etc.); y d) aumento del flujo de visitantes a los monumentos. En general, los efectos positivos del turismo cultural sobre el territorio y su economía son bien visibles. Pero la amenaza de cualquier proceso de masificación turística en un espacio frágil de alta montaña

58 Gili, 2000.

59 Roigé, 2009. 
Tabla 6. Presencia de los edificios románicos catalogados como bienes culturales de interés nacional (BCIN) de la región del Alt Pirineu i Aran en guías e itinerarios turísticos. 2015

\begin{tabular}{|c|c|c|c|c|c|c|c|c|c|}
\hline \multirow[t]{2}{*}{ Comarca } & \multirow{2}{*}{$\begin{array}{l}\text { Edificio religioso de estilo } \\
\text { románico BCIN e incoado BCIN }\end{array}$} & \multirow[t]{2}{*}{ Municipio } & \multicolumn{2}{|c|}{ Guías Románico (*) } & \multicolumn{5}{|c|}{ Rutas y marcas turísticas $(* *)$} \\
\hline & & & 1 & 2 & a & $\mathrm{b}$ & c & d & e \\
\hline \multirow[t]{8}{*}{ Alt Urgell } & Catedral de Santa Maria & La Seu d'Urgell & $* * *$ & $* * *$ & $\mathrm{X}$ & & & $\mathrm{X}$ & \\
\hline & Sant Climent de Coll de Nargó & Coll de Nargó & $* * *$ & & & & & $\mathrm{x}$ & \\
\hline & Sant Romà de Valldarques & Coll de Nargó & * & & & & & $\mathrm{x}$ & \\
\hline & Sant Esteve d'Alinyà & Fígols i Alinyà & & & & & & $\mathrm{x}$ & \\
\hline & Santa Maria d'Organyà & Organyà & & & $\mathrm{X}$ & & & $\mathrm{X}$ & \\
\hline & Sant Sadurní de Tavèrnoles & Valls de Valira, les & & & & & & $\mathrm{x}$ & \\
\hline & Sant Martí d'Ars & Valls de Valira, les & ** & & & & & $\mathrm{x}$ & \\
\hline & Sant Martí de Bescaran & Valls de Valira, les & ** & & & & & $\mathrm{x}$ & \\
\hline \multirow{11}{*}{$\begin{array}{l}\text { Alta } \\
\text { Ribagorça }\end{array}$} & Sant Climent d'Iran & Pont de Suert, el & & & & & & & \\
\hline & Santa Maria de Viu de Llevata & Pont de Suert, el & & & & & & & \\
\hline & Sant Quirc de Durro & Vall de Boí, la & & & $\mathrm{X}$ & $\mathrm{X}$ & & & \\
\hline & L’Assumpció de Cóll & Vall de Boí, la & & & & $\mathrm{X}$ & & & \\
\hline & La Nativitat de Durro & Vall de Boí, la & & & $\mathrm{X}$ & $\mathrm{X}$ & & & \\
\hline & Sant Climent de Taüll & Vall de Boí, la & $* * *$ & $* * *$ & $\mathrm{x}$ & $\mathrm{X}$ & & & \\
\hline & Santa Maria de Taüll & Vall de Boí, la & * & & $\mathrm{X}$ & $\mathrm{X}$ & & & \\
\hline & Sant Joan de Boí & Vall de Boí, la & & & $\mathrm{x}$ & $\mathrm{X}$ & & & \\
\hline & Santa Eulàlia d'Erill la Vall & Vall de Boí, la & ** & & $\mathrm{x}$ & $\mathrm{X}$ & & & \\
\hline & Sant Feliu de Barruera & Vall de Boí, la & & & $\mathrm{X}$ & $\mathrm{X}$ & & & \\
\hline & Santa Maria de Cardet & Vall de Boí, la & & & & $\mathrm{x}$ & & & \\
\hline \multirow[t]{7}{*}{ Cerdanya } & Santa Eugènia de Nerellà & Bellver de Cerdanya & * & & & & & $x$ & \\
\hline & Santa Maria de Talló & Bellver de Cerdanya & & & & & & $\mathrm{x}$ & \\
\hline & Sant Julià de Pedra & Bellver de Cerdanya & & & & & & $\mathrm{x}$ & \\
\hline & Santa Maria d'All & Isòvol & * & & & & & $\mathrm{x}$ & \\
\hline & Santa Eugènia de Saga & Ger & * & & & & & $\mathrm{x}$ & \\
\hline & Sant Esteve de Guils & Guils de Cerdanya & * & & & & & $\mathrm{x}$ & \\
\hline & Sant Serni de Meranges & Meranges & & & & & & $x$ & \\
\hline \multirow{5}{*}{$\begin{array}{l}\text { Pallars } \\
\text { Jussà }\end{array}$} & Sant Esteve d'Abella & Abella de la Conca & * & & & & & & \\
\hline & Santa Maria de Mur & Castell de Mur & * & & $\mathrm{x}$ & & $\mathrm{X}$ & & \\
\hline & Santa Maria de Covet & Isona i Conca Dellà & $* * *$ & & $\mathrm{x}$ & & & & \\
\hline & Sant Martí de la Torre & Torre de Capdella, la & & & & & & & \\
\hline & Sant Vicenç de Capdella & Torre de Capdella, la & & & & & & & \\
\hline \multirow{8}{*}{$\begin{array}{l}\text { Pallars } \\
\text { Sobirà }\end{array}$} & Sant Llíser d'Alòs d'Isil & Alt Àneu & * & & & & & & \\
\hline & Sant Joan d'Isil & Alt Àneu & ** & & $\mathrm{x}$ & & $\mathrm{X}$ & & \\
\hline & Sant llorenç d'Isavarre & Alt Àneu & & & $\mathrm{x}$ & & & & \\
\hline & Sant Just i Sant Pastor de Son & Alt Àneu & * & & & & $\mathrm{X}$ & & \\
\hline & Sant Pere del Burgal & Guingueta d'Àneu, la & * & & $\mathrm{X}$ & & $\mathrm{X}$ & & \\
\hline & Santa Maria d'Àneu & Guingueta d'Àneu, la & & & $\mathrm{x}$ & & $\mathrm{x}$ & & \\
\hline & Santa Maria de Ribera de Cardós & Ribera de Cardós & ** & & & & & & \\
\hline & Santa Maria de Gerri de la Sal & Baix Pallars & * & & & & $\mathrm{X}$ & & \\
\hline \multirow[t]{9}{*}{ Aran } & La Mare de Déu de la Purificació & Bossòst & * & & & & & & $\mathrm{x}$ \\
\hline & Santa Maria d'Arties & Naut Aran & & & $\mathrm{X}$ & & & & $\mathrm{X}$ \\
\hline & Santa Eulàlia d'Unha & Naut Aran & & & & & & & $\mathrm{x}$ \\
\hline & Santa Maria de Cap d'Aran & Naut Aran & & & & & & & $\mathrm{x}$ \\
\hline & Sant Andreu de Salardú & Naut Aran & & & & & & & $\mathrm{X}$ \\
\hline & Sant Pere d'Escunhau & Vielha e Mijaran & * & & & & & & $\mathrm{x}$ \\
\hline & Sant Feliu de Vilac & Vielha e Mijaran & & & & & & & $\mathrm{x}$ \\
\hline & Sant Miguèu de Vielha & Vielha e Mijaran & & & & & & & $\mathrm{X}$ \\
\hline & Santa Maria de Vilamòs & Vielha e Mijaran & & & & & & & $\mathrm{X}$ \\
\hline
\end{tabular}

Fuente: Elaboración propia

1. Presente en la guía de Buron. 2. Catalogada de interés en la guía Zodiaque. a. Pirineo Condal. b. Románico de la Vall de Boí. c. Ecomuseo de les Valls d'Àneu Joc de Dames. d. Via Romànica

*Nota: 1. Guia iglesies romàniques catalanes de Vicenç Buron $(*$ = grado de interés artístico); 2. Catalogne Romane, Zodiaque.

**Nota: a. Ruta Pirineo Condal, b. Románico de la Vall de Boí, c. Ecomuseo de les Valls d'Àneu, d. Vía Románica y e. Val d'Aran Románico. 
también existe y, de producirse, podría comprometer la viabilidad del actual modelo de desarrollo turístico, basado en la patrimonialización de su paisaje.

En cuanto a la dimensión turística del conjunto patrimonial, a partir del análisis de la demanda se pone de manifiesto, en primer lugar, el "efecto llamada" que causó el reconocimiento internacional del románico en el año 2000. Así, por ejemplo, un año después de su declaración, los visitantes aumentaron en más de 50.000, pasando de los 73.905 turistas en el año 2000 a los casi 125.000 en el 2001. La afluencia de público al conjunto de iglesias románicas fue al alza hasta el año 2007, justo antes del inicio de la crisis económica, con una cifra récord de 157.026 visitantes en ese mismo año. Los efectos de la crisis repercutieron directamente sobre el turismo y el número total de visitantes se redujo a partir del año 2008, a pesar de un breve repunte en 2011 . No es hasta el año 2014 que el sector se recupera de nuevo, con un incremento más lento pero sostenido de la demanda (figura 9).

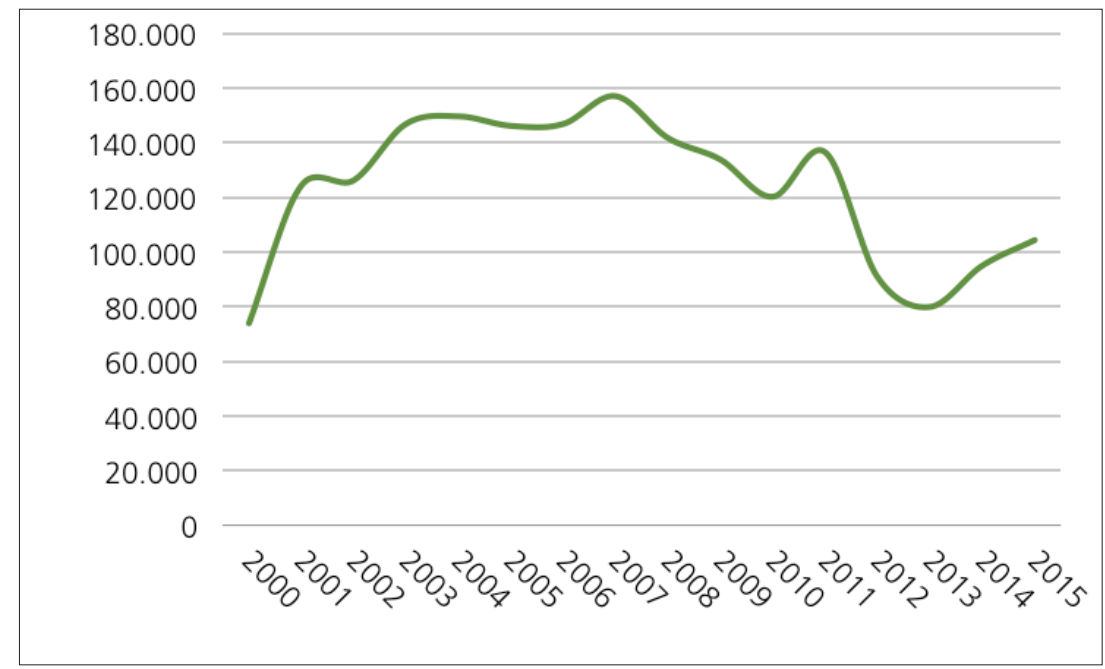

Figura 9. Evolución del número total de visitantes al conjunto románico de la Vall de Boí (2000-2015)

Fuente: Elaboración propia a partir de los datos de la Oficina de Turismo de la Vall de Boí

Tal y como sucede con el resto de prácticas turísticas, salvo con el turismo de nieve, el pico máximo de afluencia de visitantes al conjunto monumental se produce durante los meses de verano, principalmente durante agosto, coincidiendo con el periodo vacacional. Durante el resto del año, la afluencia turística desciende rápidamente, con dos repuntes secundarios en Semana Santa y Navidades (figura 11). Se aprecia de nuevo que, pese a la existencia en la zona de la estación de esquí alpino Boí Taüll Resort (generadora de un importante flujo de visitantes durante los meses de invierno y que promociona el románico como actividad complementaria al esquí), el número de visitas a los monumentos durante este periodo del año es muy bajo. La complejidad y dificultad, en términos de producto y demanda, a la hora de relacionar las dos modalidades de turismo parecen evidentes. Partiendo de la hipótesis que son actividades de naturaleza y funcionamiento muy distintas, con públicos igualmente diferentes, las interrelaciones que se puedan establecer entre ambas 
no parecen fáciles. Pero en el actual escenario de cambio climático, el románico y sus espacios deberían jugar un papel más activo en cuanto a oferta complementaria al esquí. En este caso, desde una perspectiva de complementariedad al turismo de nieve, se deben tener en cuenta aspectos como la gestión del calendario de apertura y visita a los monumentos ${ }^{60}$ o la programación de actividades destinadas al público esquiador.

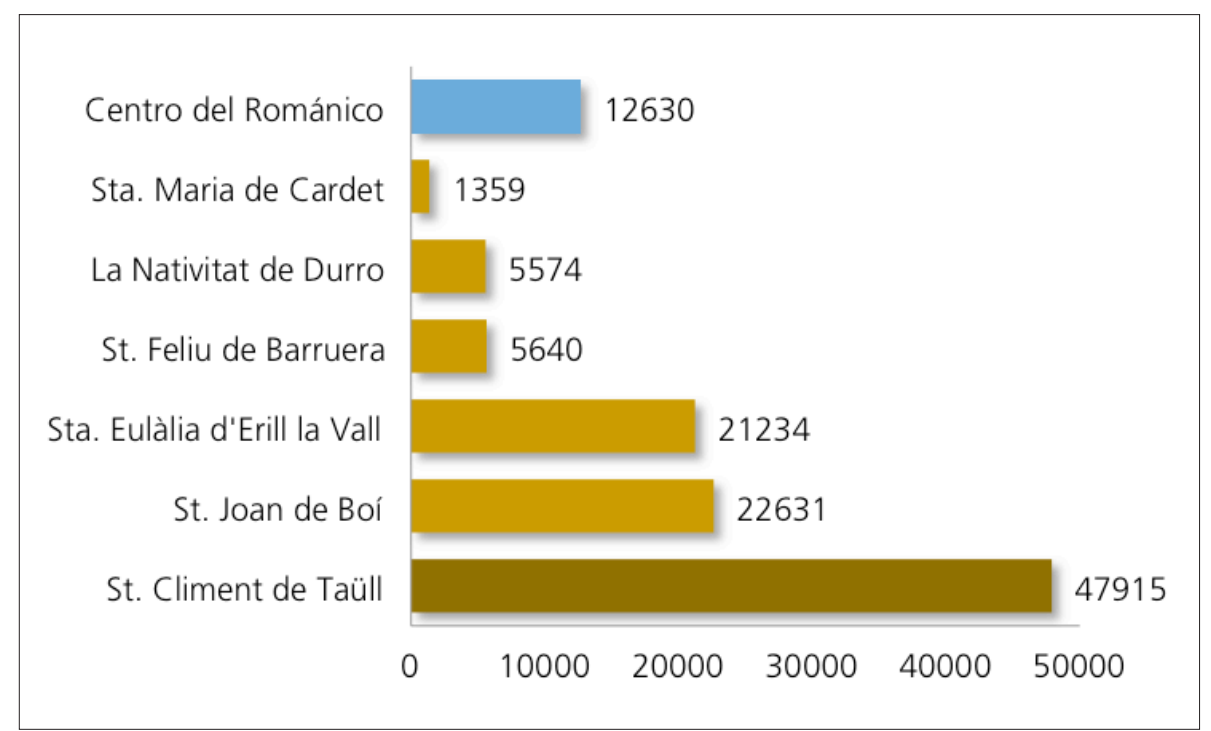

Figura 10. Distribución del número total de visitantes en la Vall de Boí según lugar de vista, 2015

Fuente: Elaboración propia a partir de los datos de la Oficina de Turismo de la Vall de Boí

Continuando con el análisis turístico del patrimonio monumental de la Vall de Boí, del conjunto de iglesias que forman la oferta románica, la de Sant Climent de Taüll ${ }^{61}$ es, sin duda, la más visitada de toda ellas, con una media anual de visitantes para el período 1999-2015 que se sitúa en los 55.398. Se observa, a partir de la distribución de los visitantes por monumentos, que la presión turística en Sant Climent de Taüll es muy superior al resto de iglesias románicas, recibiendo más del doble de visitantes que el segundo edificio más visitado, la iglesia de Sant Joan de Boí (figura 10). Además, la afluencia turística en Sant Climent de Taüll es especialmente elevada en Semana Santa y durante el mes de agosto, con una frecuentación media diaria de aproximadamente 500 visitas, y una afluencia media mensual en agosto superior a los 15.000 visitantes (figura 11). Debido a las características físicas del propio edificio, espacio relativamente reducido, y a la gran afluencia de turistas en determinados períodos del año, la gestión de los flujos se convierte en una de las principales

60 Las iglesias de Sant Climent de Taüll, Santa Maria de Taüll, Sant Joan de Boó y Santa Eulàlia d'Erill la Vall son visitables durante todo el año, excepto el día 25 de diciembre y l de enero; y excepto durante el mes de noviembre para los casos de Sant Joan de Boí y Santa Eulàlia d'Erill la Vall, que permanecen cerradas.

61 Sant Climent de Taüll es la iglesia más emblemática y monumental del conjunto patrimonial, tanto por su esbelto campanario de torre cuadrada de seis pisos con decoración lombarda como por la museización en su interior, que gracias a las modernas técnicas audiovisuales reproducen con todo detalle el proceso pictórico con el pantocrátor como figura central de la obra. 
tareas de los órganos responsables, al fin de no superar la llamada "capacidad de carga turística" del monumento y garantizar en todo momento su correcta conservación. En definitiva, en la Vall de Boí se puede entrever un amago de masificación turística en ciertos espacios patrimoniales en momentos puntuales del año, siendo una problemática que, a menudo, no es de fácil resolución ya que la estacionalidad es inherente al funcionamiento del propio sistema turístico.

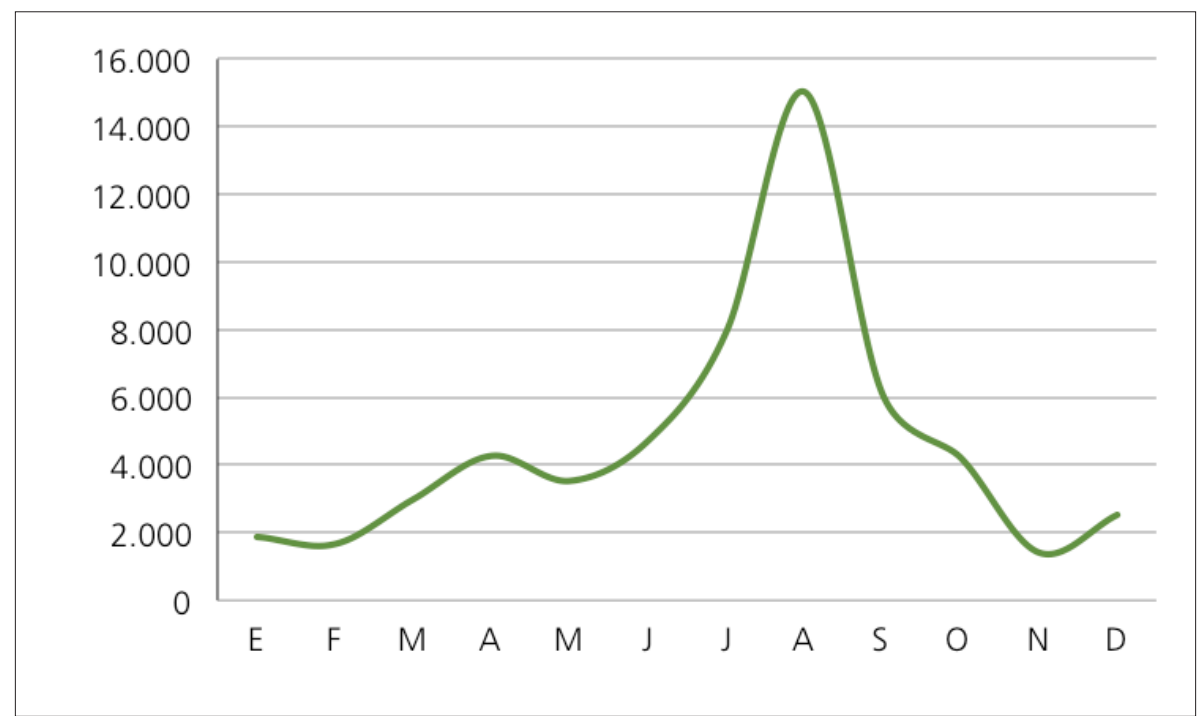

Figura 11. Distribución del número medio mensual de visitantes en la iglesia de Sant Climent de Taüll (1999-2015)

Fuente: Elaboración propia a partir de los datos de la Oficina de Turismo de la Vall de Boí

Finalmente, en cuanto a procedencia de la demanda, cabe señalar que pese a la internalización y globalización del producto patrimonial debido a la marca de la UNESCO, en la Vall de Boí hoy por hoy predomina el turismo interno y de proximidad, tal y como sucede en el resto de la región pirenaica. A partir de las consultas recibidas en la sede de la Oficina de Turismo de la Vall de Boí a lo largo del año 2015, el 61 por ciento de las consultas procedían de Cataluña, el 28 por ciento del resto de España y el 11 por ciento de países extranjeros, principalmente de Francia. En el ámbito del turismo internacional cabe destacar en los últimos años el aumento del turismo israelí: 1,2 por ciento del total de consultas atendidas, pero con una presencia muy notable en el Parque Nacional de Aigüestortes i Estany de Sant Maurici ( 32 por ciento del total de visitantes extranjeros en 2014). Sin disponer aun de datos suficientes y contrastados, la hipótesis de que el turista israelí, que acude al Parque Natural de Aigüestortes en verano y a las pistas de esquí de Boí Taüll en invierno ${ }^{62}$, visite también el conjunto románico de la zona parece verosímil, ya que por lo general es un perfil de turista interesado en conocer el patrimonio histórico de los Pirineos, en parte debido al proyecto de memoria histórica "Perseguits i salvats" sobre la huida del pueblo judío a través de los Pirineos durante la Segunda Guerra Mundial.

62 Existe un vuelo semana entre Tel Aviv y el Aeropuerto de Lleida-Alguaire para acercar el mercado israelí a los Pirineos. 


\section{Conclusión}

A modo de conclusión cabría destacar, en primer lugar y para el caso de la Vall de Boí, la existencia de una doble funcionalidad turística, con impactos territoriales y económicos distintos ${ }^{63}$. Por un lado, la presencia del turismo basado en el patrimonio natural y cultural, a priori más sostenible, y que ha ganado peso y presencia en la zona tras ser reconocido por la UNESCO. Por otro, en el polo opuesto, la presencia de un turismo de masas basado en la práctica del esquí. Son actividades difícilmente comparables y compatibles, desde un punto de vista cualitativo y en cuanto a sus públicos, pero que, en términos de estacionalidad, son absolutamente complementarias. En el municipio de la Vall de Boí, los procesos de patrimonialización territorial han marcado la pauta de su desarrollo a lo largo de los últimos tiempos; la puesta en valor del patrimonio natural y cultural, en términos de conservación y disfrute turístico, ha permitido consolidar la diversificación de modalidades y productos turísticos en la zona, para a la vez, dar respuesta a una mayor segmentación de la demanda. Un modelo turístico diversificado fortalece, en principio, la capacidad de respuesta del territorio ante nuevos desafíos como, por ejemplo, el del cambio climático, al hacerlo menos dependiente de modalidades turísticas altamente sensibles al tiempo meteorológico y al clima.

Ampliando el ángulo de observación al resto del Pirineo occidental catalán, tras comprobar el elevado potencial turístico de la zona gracias a la gran cantidad de monumentos histórico-artísticos catalogados e integrados en sus respectivos paisajes rurales, la puesta en valor del patrimonio cultural con fines turísticos es una opción para diversificar la oferta y los productos turísticos de los Pirineos y romper, de algún modo, con la marcada y estructural estacionalidad turística. En este sentido, el grupo de acción local para el desarrollo rural de las comarcas del Aran, Alta Ribagorça, Pallars Jussà y Pallars Sobirà, el Consorci Leader Pirineu Occidental, contempla la desestacionalización turística como una de sus líneas estratégicas de actuación para el periodo 2014-2020; y con esta finalidad, parte de las ayudas irán destinadas a la recuperación del patrimonio cultural y natural.

Las virtudes del turismo cultural en zonas de montaña no son pocas: a) contribuye a la restauración y conservación del patrimonio etnológico y paisajístico; b) genera sinergias con el turismo rural y de naturaleza a escala local; c) presenta un elevado potencial de desarrollo en base a la gran cantidad de recursos patrimoniales en buen estado de conservación; d) no depende de factores ambientales externos; y e) contribuye a ampliar y diversificar la oferta de productos turísticos. No es menos cierto que el binomio patrimonio-turismo presenta algunos aspectos ambiguos y complejos: a) el diálogo que se establece entre preservación y frecuentación turística, que para el caso de los Pirineos no es por ahora un tema conflictivo pero que sí lo podría ser en un futuro si hubiera un incremento notable del número de visitantes durante la estación de verano; b) la dificultad para crear verdaderos productos turísticos articulados en torno al eje patrimonial, y con implicación activa de

63 Gili, 2000. 
la iniciativa privada; y c) el encaje y/o convivencia con otros tipos de turismo muy consolidados en la zona, como por ejemplo el turismo de nieve. En este sentido, el patrimonio monumental puede ser igualmente objeto de uso y disfrute durante los meses invernales, dada su escasa dependencia de los factores ambientales de tipo atmosférico, y, sin embargo, el análisis temporal de los flujos turísticos hacia este tipo de recursos indican una muy baja frecuentación durante este época del año, a pesar de la elevada presencia de esquiadores en la zona.

En definitiva, el potencial desarrollo territorial y turístico de la región del Alto Pirineo y Aran en base al patrimonio cultural es elevado, estando muy presente en las actuales políticas territoriales de desarrollo -a escala local y regional- con un discurso casi unánime respecto a sus bondades y como elemento clave y de futuro en los llamados procesos de desarrollo "endógeno" de los territorios. La puesta en valor de los recursos patrimoniales está directamente relacionada con las políticas de conservación de aquellos elementos paisajísticos que configuran la identidad de un territorio, así como con la recuperación de la memoria histórica. La actividad turística abre la posibilidad de recuperar de nuevo muchos de aquellos monumentos que habían caído en el olvido y el abandono; y a pesar de los riesgos que supone el turismo cuando este se presenta bajo formas masificadas y estandarizadas, y más aún cuando el capital es de origen exógeno, en la zona de estudio no parece que se den, por el momento, estas circunstancias. En conclusión, los actores locales apuestan por dar un mayor protagonismo y relevancia al patrimonio monumental en un territorio altamente dependiente del turismo.

Sin embargo, más allá de la riqueza y de los procesos de puesta en valor del patrimonio histórico-artístico en la región, que son innegables, cabe plantearse una serie de reflexiones en clave de interrogantes con respeto a su relación con el turismo de nieve, uno de los grandes motores económicos de los Pirineos: ¿es compatible el turismo de nieve con el turismo cultural en cuanto a gestión de los productos y al perfil de la demanda?; ¿la gestión del sistema turístico en territorios de montaña es la adecuada para fortalecer las sinergias entre ambos tipos de turismo, y así dar respuesta a las estrategias de adaptación al cambio climático?; ¿hasta qué punto las estaciones de esquí tienen en cuenta el patrimonio cultural como alternativa y/o complemento ante una eventual falta del recurso nieve? o bien ¿los órganos responsables de la oferta cultural contemplan al esquiador como un cliente potencial que supla la escasa afluencia de visitantes en invierno? Son interrogantes ante los que seguir indagando e intentar dar respuesta en futuros estudios.

\section{Bibliografía}

ALBARRÁN, José David. El concepto de patrimonio territorial: problemáticas de gestión y planificación turística. In BLÁZQUEZ, Macià; MIR-GUAL, Miquel; MURRAY, Ivan y PONS, Guillem X. Turismo y crisis, turismo colaborativo $y$ ecoturismo. XV Coloquio de Geografía del Turismo, el Ocio y la Recreación de la AGE. Palma de Mallorca: Societat d'història Natural de les Balears, 2016, p. 67-78. 
BURON, Vicenç. Esglesies romàniques catalanes. Guia. Barcelona: Artestudi Edicions, $1980.419 \mathrm{p}$.

CÀNOVES, Gemma. (dir.). El turisme rural a Catalunya. Una aportació mediambiental $i$ de qualitat. Barcelona: Fundació Abertis-Departament de Geografia UAB, 2004.

CAÑIZARES, Ma Carmen. Protección y defensa del patrimonio minero en España. Scripta Nova, Revista Electrónica de Geografía y Ciencias Sociales. [En línea]. Barcelona: Universidad de Barcelona, 201 1, vol.XV, no 361.<http://www.ub.edu/ geocrit/sn/sn-361.htm. ISSN: 1138-9788>.

CAPEL, Horacio. El patrimonio: la construcción del pasado y del futuro. Barcelona: ediciones del Serbal, 2014. $183 \mathrm{p}$.

CORS, Martí; GÓMEZ, Ma Belén y ARMESTO, Xosé A. Estrategias de diversificación y desestacionalización turística en espacios de alta montaña. El caso de la Vall de Boí (Lleida). In GARCÍA, Ramón; ALONSO, Francisco; BELMONTE, Francisco y MORENO, Daniel (eds.). Actas XV Coloquio Ibérico de Geografía. Retos y tendencias de la geografía ibérica. Murcia: Asociación de Geógrafos Españoles, Associaçâo Portuguesa de Geógrafos y Universidad de Murcia, 2016, p. 468-477.

CORS, Martí. Patrimoni rural i turisme. In LÓPEZ-PALOMEQUE, Francesc. (coord.). Atles del turisme a Catalunya. Mapa nacional de l'oferta $i$ els productes turístics. Barcelona: Generalitat de Catalunya, 2009, p. 65-72.

CORS, Martí. Patrimonio histórico y atracción turístico-cultural. El Museo Diocesano de Solsona (Cataluña). In MORALES, Guillermo. (ed.). Actas Turismo y Ciudad. Las Palmas de Gran Canaria: Guillermo Morales, 2000, p. 122-129.

DE LA CALLE, Manuel. La ciudad histórica como destino turístico. Madrid: Síntesis, 2002.302 p.

DELGADO, Carmen; GIL, Carmen; HORTELANO, Luís Alfonso y PLAZA, Juan Ignacio. Turismo y desarrollo en algunas comarcas de la montaña cantábrica: recursos y planificación. Cuadernos de Turismo, 2003, nº 12, p. 7-34.

DELGADO, Manuel. Trivalidad y trascendencia. Usos sociales y políticos del turismo cultural. In Turismo cultural: el patrimonio histórico como fuente de riqueza. Valladolid: Fundación del Patrimonio Histórico de Castilla y León, 2000, p. 3352.

DOCTOR, Alfonso, M. El itinerario como herramienta para la puesta en valor turístico del patrimonio territorial. Cuadernos de turismo, 2011 , no 27, p. 273-289.

DURLIAT, Marcel. La Catalogne et "le premier art roman". Bulletin Monumental, 1989, Vol. 147, n³, p. 209-238.

FONT, Jaume. Turismo y políticas turísticas en el Pirineo catalán, Ambiente y derecho, 2012, no 10, p. 43-65.

FRAGUELL, Rosa; GÓMEZ, Ma Belén ; LLURDÉS, Joan Carles; MARTÍ, Carolina; RIBAS, Anna y SAURÍ, David. Turisme. In MARTIN VIDE, Javier (Coord.) Tercer Informe del Canvi Climàtic a Catalunya. Barcelona: Generalitat de Catalunya i Institut d'Estudis Catalans, 2016, p. 383-408. 
FRANÇOIS, Hugues; HIRCZAK, Maud y SENIL, Nicolas. Territoire et patrimoine: la coconstruction d'une dynamique et de ses ressources. Revue d'Éonomie Régionale \& Urbaine, 2006/5, p. 283-700.

GARCÍA, Antonio, y ALBURQUERQUE, Francisco Javier. El turismo cultural y el de sol y playa: ¿sustitutivos o complementarios?. Cuadernos de Turismo, 2003, $\mathrm{n}^{\circ}$ $11, p-97-105$.

GARCÍA, María y DE LA CALLE, Manuel. Los hitos patrimoniales en dimensión turística. Castilla y León y la Real Colegiata de San Isidoro. Polígonos. Revista de Geografía, 2012, no 23, p. 113-145.

GARCÍA, María. Entidades de planificación y gestión turística a escala local. El caso de las ciudades Patrimonio de la Humanidad en España. Cuadernos de Turismo, 2007, n² 20, p. 79-102.

GENERALITAT DE CATALUNYA. Pla Director Urbanístic de la Val d'Aran. Memòria de l'ordenació. Barcelona: Departament de Política Territorial i Obres Públiques, 2010.239 p.

GENERALITAT DE CATALUNYA. Pla Director Urbanístic del Pallars Sobirà. Memòria de l'ordenació. Barcelona: Departament de Política Territorial i Obres Públiques, 2008. 107 p.

GENERALITAT DE CATALUNYA. Pla Territorial de l'Alt Pirineu i Aran. Memòria (Vol. 2). Barcelona: Departament de Política Territorial i Obres Públiques, 2006.

GENERALITAT DE CATALUNYA. Plans Comarcals de Muntanya 2001-2005. Barcelona: Departament de Política Territorial i Obres Públiques, 2002.

GENERALITAT DE CATALUNYA. Plans Comarcals de Muntanya 2009-2012. Barcelona: Departament de Territori i Sostenibilitat, 2009.

GENERALITAT DE CATALUNYA. Rutes i intangibles com a estratègia de posada en valor turístic del patrimoni pirinenc. Pirineu Comtal. Un viatge pel naixement de Catalunya. In El turisme pirinenc en l'horitzó del 2000. Tendències, mercats $i$ estratègies. Segones Jornades Econòmiques de l'Alt Pirineu i Aran, Alp. 2010.

GILI, Mercè. Conservación del patrimonio y turismo de masas: el caso de un municipio de montaña, Vall de Boí (Cataluña)". In MORALES, Guillermo. (ed.). Actas Turismo y Ciudad. Las Palmas de Gran Canaria: Guillermo Morales, 2000, p. 130-140.

GÓMEZ, Ma Belén. Reflexión geográfica en torno al binomio clima-turismo. Boletín de la Asociación de Geógrafos Españoles, 2005, nº 40, p. 111-134.

GÓMEZ, Ma Belén; ARMESTO, Xosè; CORS, Martí y MUÑOZ, Jenny. Adaptation strategies to climate change in the tourist sector: the case of coastal tourism in Spain. Tourism. An International Interdisciplinary Journal, 2014, nº 62(3), p. 293308. 
GÓMEZ, Ma Belén; ARMESTO, Xosé y CORS, Martí. Crisis económica y estaciones de esquí en las comarcas catalanas de la Val d'Aran, Pallars Sobirà y Alta Ribagorça. In BLÀZQUEZ, Macià; MIR-GUAL, M.; MURRAY, I. y PONS, G.X. (eds.). Turismo y crisis, turismo colaborativo y ecoturismo. XV Coloquio de Geografía del Turismo, el Ocio y la Recreación de la AGE. Palma: Monografies de la Societat d'Història Natural de les Balears, 23, 2016, p. 213-223.

GÓMEZ-MENDOZA, Josefina. Del patrimonio paisaje a los paisajes patrimonio. Documents d'Anàlisi Geogràfica, 2013, vol. 59, nº 1, p. 5-20.

GÓMEZ, Antonio; OLIVA, Marc; SALVÀ, Montserrat y SALVADOR, Ferran. El paisaje como valor patrimonial. El caso del Parque Nacional de Sierra Nevada (España). Scripta Nova, Revista Electrónica de Geografía y Ciencias Sociales. [En línea]. Barcelona: Universidad de Barcelona, 2010, vol. XIV, $\mathrm{n}^{\circ}$ 346. <http://www. ub.edu/geocrit/sn/sn-346.htm. ISSN: 1138-9788>.

GRAHAM, Brian; ASHWORTH, G.J. y TUNBRIDGE, J.E. A Geography of Heritage. Power, Culture \& Economy. London: Arnold, 2000. 284 p.

HARVEY, David. The condition of Posmodernity. Oxford: Blackwell, 1989.

HERNÁNDEZ, Javier. Los caminos del patrimonio. Rutas turísticas e itinerarios culturales. Pasos, 2011 , Vol. 9 no 2, p. 225-236.

IDESCAT. Anuari estadistic de Catalunya 2015. Barcelona: Generalitat de Catalunya.

JIMÉNEZ, Sole. El turisme a muntanya: de la mentalitat a la racionalitat. El cas del Pallars Sobirà. Revista d'etnologia de Catalunya, 2003, nº 22, p. 54-67.

JUNYENT, Eduard. Catalogne Romane I. París: Zodiaque, 1960. 287 p.

LAZZAROTTI, Olivier. Patrimoine et tourisme. Histoires, lieux, acteurs, enjeux. París: Belin, 2011.302 p.

LÓPEZ-PALOMEQUE, Francesc. Definición conceptual y tipologías de turismo rural. In PULIDO, Juan Ignacio. (coord.). El turismo rural. Madrid: Síntesis, 2008, p. 21 49.

LÓPEZ-PALOMEQUE, Francesc. Neu i estacions d'esquí i muntanya. In LÓPEZPALOQUE, Francesc (coord.). Atles del turisme a Catalunya. Mapa nacional de l'oferta i els productes turístics. Barcelona: Generalitat de Catalunya, 2009, p. 167177.

MADERUELO, Javier. (dir.). Paisaje y patrimonio. Madrid: Abada Editores, 2010. 353 p.

MARTÍ-HENNEBERG, Jordi. L'excursionisme Cientific. Barcelona: Altafulla, 1994.

MARTÍN, María Isabel. Patrimonio y paisaje en España y Portugal. Del valor singular a la integración territorial. Boletín de la Asociación de Geógrafos Españoles, 2016, no 71, p. 347-374.

MARTÍNEZ, Guadalupe. Qhapaq Ñan: El Camino Inca y las transformaciones territoriales en los Andes peruanos. Ería, 2009, no 78-79, p. 21-38.

MOLINA, José; TUDELA, Ma Luz y GUILLÉN, Virginia. Potenciación del patrimonio natural, cultural y paisajístico con el diseño de itinerarios turísticos. Cuadernos de turismo, 2014, no 34, p. 189-211. 
MORENO, R. y PEREIRA, M.: Arica y Parinacota: La Iglesia en la Ruta de la Plata. Viña del Mar: Ediciones Altazor, 2011 , p. 154.

OJEDA, Juan Fco. El paisaje -como patrimonio- factor de desarrollo de las áreas de montaña. Boletín de la A.G.E., 2004, n 38, p. 273-278.

ORTEGA, José. Áreas de montaña: de la supervivencia a la integración. Boletín de la A.G:E., 2004, no 38, p. 5-28.

ORTEGA, José. El patrimonio territorial. El territorio como recurso cultural y económico. Revista Ciudades, 1998, nº 4, p. 33-48.

PEREIRO, X. Turismo cultural. Uma visiao antropológica. Pasos. Revista de Turismo y Patrimonio Cultural, 2009, Colección no 2.

PILLET, Félix. El turismo de interior y el patrimonio territorial en Castilla-La Mancha. Cuadernos de Turismo, 2011, no 27, p. 725-741.

PORCAL, $\mathrm{M}^{\mathrm{a}}$ Cruz. El patrimonio rural como recurso turístico. La puesta en valor turístico de infraestructuras territoriales (rutas, y caminos en las áreas de montaña del País Vasco y Navarra. Cuadernos de Turismo, 201 1, n 27, p. 759-784.

PRALONG, Jean-Pierre. Pour une mise en valeur touristique et cuturelle des patrimonies de l'espace alpin: le concep d'histoire. Histoire des Alpes, 2004/9, p. 301-310.

PRATS, Llorenç. El concepto de patrimonio cultural. Politica y Sociedad, 1998, n 27, p. 63-76.

PRATS, Llorenç. La viabilidad turística del patrimonio. Pasos. Revista de turismo y patrimonio cultural, 2011, vol. 9, n 2, p. 249-264.

PULIDO, Juan Ignacio (coord.), DE LA CALLE, Manuel y VELASCO, Maria. Turismo cultural. Madrid: Síntesis, 2013.298 p.

RIVERA, Javier. Paisaje y patrimonio. In MADERUELO, Javier. (dir.). Paisaje y patrimonio. Madrid: Abada Editores, 2010, p. 11-29.

ROIGÉ, Xavier. Patrimoni Històric. In LÓPEZ-PALOMEQUE, Francesc. (coord.). Atles del turisme a Catalunya. Mapa nacional de l'oferta $i$ els productes turístics. Barcelona: Generalitat de Catalunya, 2009, p. 77-89.

SILVA, Rocío. Agricultura, paisaje y patrimonio territorial. Los paisajes de la agricultura vistos como patrimonio. Boletín de la A.G.E., 2009, nº 49, p. 309-334.

SILVA, Rocío y FERNÁNDEZ, Víctor. El nuevo paradigma de patrimonio y su consideración con los paisajes. Documents d'Anàlisi Geogràfica, 2017, vol 63/1, p. 129-151.

SIMÓN, X.; GIL, C. y CARPINTERO, P. Proyecto de agroturismo en la comarca de Terra de Lemos (Galicia). Pasos. Revista de Turismo y Patrimonio Cultural, 2011 , Vol. 9, $\mathrm{n}^{\circ} 2$, p. 353-365.

SIMPSON, M.C.; GÖSSLING, S.; SCOTT, D.; HALL, C.M. y GLADIN, E. Climate Change Adaptation and Mitigation in the Tourism Sector: Frameworks, Tools and Practices. París: UNEP, University of Oxford, UNWTO, UNWMO, 2008. 
SOL, Marie-Pierre. La patrimonialisation comme (re)mise en tourisme. De quelques modalités dans les « Pyrénées catalanes «In VIOLIER, Philippe y LAZZAROTTI, Olivier. Tourisme et patrimoine. Saumur: Presses de l'Université d'Angers, 2007, p.161-175.

TROITIÑN, Libertad. La dimensión turística del patrimonio cultural de la ciudad de Lorca (Murcia, España). Cuadernos de Turismo, 2015, nº 36, p. 389-414.

TROITIÑN, Miguel Ángel. Patrimonio arquitectónico, cultura y territorio. Revista Ciudades, 1998, no 4, p. 95-104.

TROITIÑO, Miguel Ángel y TROITIÑO, Libertad. Patrimonio y turismo: una reflexión teórico-conceptual y una propuesta metodológica integradora aplicada al municipio de Carmona (Sevilla, España). Scripta Nova, Revista Electrónica de Geografía y Ciencias Sociales. [En línea]. Barcelona: Universidad de Barcelona, 2016, vol. XX, no 543, p. 1-45. <http://revistes.ub.edu/index.php/ScriptaNova/ article/view/543. ISSN: 1138-9788>.

TRONCOSO, Claudia A. Patrimonio y redefinición de un lugar turístico. La Quebrada de Humauaca, Provincia de Jujuy, Argentina. Estudios y perspectivas en Turismo. Buenos Aires: Universidad Nacional de Buenos Aires, 2009, vol 18, p. 144-160.

TULLA, Antoni F. Divisió territorial de Catalunya: algunes reflexions des de l'Alt Pirineu. Treballs de la Societat Catalana de Geografia, 2009, n 67-68, p. 273-290.

VELASCO, María. Gestión turística del patrimonio cultural: enfoques para un desarrollo sostenible del turismo cultural. Cuadernos de turismo, 2009, no 23, p. 237-253.

VALENZUELA, Alfonso. Patrimonio, turismo y mercado inmobiliario en Tepoztlán, México. Pasos. Revista de Turismo y Patrimonio Cultural, 2017, Vol. 15, nº 1, p. 181193.

VERA, Ana; BADIA, Anna y TULLA, Antoni F. Desarrollo local en el Pirineo Catalán: impulso económico y uso sostenible del territorio, Finisterra, 201 1, vol. 46, no 92 , p. 5-23.

VERA, José Fernando (coord.). Análisis territorial del turismo y planificación de destinos turísticos. Valencia: Tirant Humanidades, 2013.485 p.

(c) Copyright: Martí Cors i Iglesias; M. Belén Gómez Martín; Xosé A. Armesto López, 2018

(c) Copyright Scripta Nova, 2018.

Ficha bibliográfica:

CORS i IGLESIAS, Martí; GÓMEZ MARTÍN, M. Belén; ARMESTO LÓPEZ, Xosé A. La apuesta por el patrimonio histórico-artístico en el turismo de montaña. El caso del Pirineo catalán. Scripta Nova. Revista Electrónica de Geografia y Ciencias Sociales. [En línea]. Barcelona: Universidad de Barcelona, 15 de abril de 2018, vol. XXII, nº 588. ISSN: 1138-9788. 